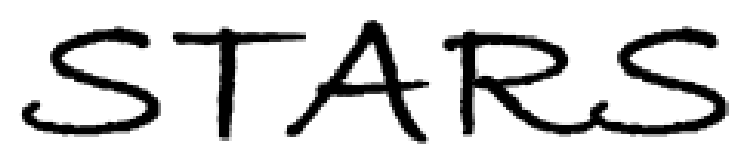

University of Central Florida

STARS

2017

\title{
Political Islam and Democracy
}

Mikellon S. Browne-Michael

University of Central Florida

Part of the Comparative Politics Commons, International Relations Commons, and the Near and Middle Eastern Studies Commons

Find similar works at: https://stars.library.ucf.edu/honorstheses

University of Central Florida Libraries http://library.ucf.edu

This Open Access is brought to you for free and open access by the UCF Theses and Dissertations at STARS. It has been accepted for inclusion in Honors Undergraduate Theses by an authorized administrator of STARS. For more information, please contact STARS@ucf.edu.

\section{Recommended Citation}

Browne-Michael, Mikellon S., "Political Islam and Democracy" (2017). Honors Undergraduate Theses. 238. https://stars.library.ucf.edu/honorstheses/238

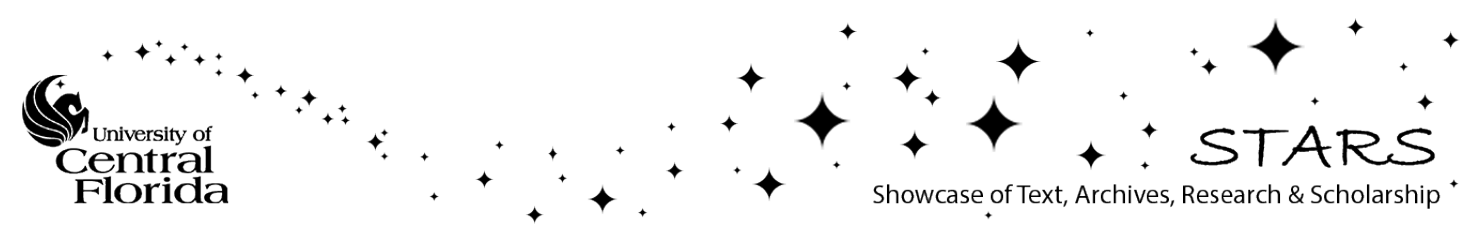




\title{
POLITICAL ISLAM AND DEMOCRACY
}

\author{
by
}

\section{MIKELLON BROWNE-MICHAEL}

A thesis submitted in partial fulfillment of the requirements

for the Honors in the Majors Program in International and Global Studies

in the College of Sciences

and in the Burnett Honors College

at the University of Central Florida

Orlando, Florida

Summer Term, 2017

Thesis Chair: Houman Sadri, Ph.D. 


\begin{abstract}
The Middle East is a predominately Islamic region. Islam is not only a religion, it is the Muslim way of life and law. The western world follows a more modern system of government, in the form of democracy. Democracy is not modern, as in new, since it was started by the ancient Greeks, but it is modern, because it is the main system being adopted in contemporary times.
\end{abstract}

Muslims follow the ideals found in the Holy Quran, the book dictated by the prophet Muhammad. The Middle East has had a strong Islamic influence since the mid-seventh century. Islam originated in Mecca in 610 C.E. About twelve years later, in 622 C.E., after much persecution in Mecca, Muslims migrated to Medina. This was in 622 C.E. and it marked the start of the Muslim calendar. Soon, by 655 C.E., Islam had begun spreading over the regions along the Mediterranean Sea, Arabian Peninsula, Asia, and Africa. This research will span the political systems from pre-Ottoman, to Ottoman, to the Modern era. The beginning of the modern Middle East is marked by the collapse of the Ottoman Empire and the end of World War I. Since the end of World War I, much of the Middle Eastern region has been exposed to the western system of government and western culture.

The intent of this Thesis is to analyze and draw a conclusion on the possibility of Politically Islamic states having Democracy and following Democratic ideologies. It will examine the ideologies of Islam to determine if democracy, a system of government that includes the 
citizens of the nation having the right to speak and receiving civil liberties to choose their leaders, is actually present. It will use data from Turkey, Iran, and Egypt, Middle Eastern nations located either in, or bordering, three different continents of the world. In each country the research will examine, the governmental system, the regime type, the leaders past and present, and the policies, including how each country vary according to a specific Islamic sector (Sunni or Shia). This thesis will draw conclusions from the comparative analysis on each case study, on whether it is possible to have democracy in a state where Islamic ideologies are a major factor.

From the case study findings, there were clear differences between all the countries studied. Turkey was found to be majority Sunni with a secular republic government but it is showing signs of reverting into the realm of political Islam. Iran was found to be majority Shia with a religious republic government, one that freely allows religion into the law-making body and has emphasized policies that are based on Islamic law. In addition, Iran shows adversity to western democratic bodies, which falls in line with the idea that Islam and democracy are at odds. Finally, Egypt the most revolution-plagued has changed leaders constantly through coups and protests, when the citizens find the leaders as corrupt or not acting in the best interest of the country. Like Turkey, Egypt is a secular republic with the majority of its citizens being from the Sunni Islamic sect it has recently shown an inclination to be the most democratic nation of those studied.

The research showed that the Middle East is still having trouble adjusting to the idea of democracy and democratic ideology. The issues were found on various cultural, social, and 
leadership levels. There were not only civil and regional disputes among the nations of the Middle East, some of the issues have been extended to international levels. The split between Democracy and traditional Islamic values, appeared to only deepen the conflicts of the region. 


\section{ACKNOWLEDGMENTS}

I would like to thank the chair of my thesis committee, Dr. Houman Sadri, who kept me focused and gave me the encouragement that I can succeed. From the first day when I contacted him on doing and completing a research thesis, his enthusiasm gave me great confidence that the task ahead of me was within my grasp. He was always accessible and willing to share his knowledge and expertise. I appreciate Dr. Sadri's guidance from start to finish.

I would also like to thank my other committee members Dr. Robert Bledsoe and Professor Hadi Abbas, who were always ready to assist, and made sure that my paper was staying on topic and had relevant sources. This research would not have been possible without the continued advice, patience and support of each committee member. They helped me build on my ideas and gave suggestions, which advanced this paper and my research skills significantly.

I would also like to give special thanks to Professor Roberta Vandermast of Valencia College. She was instrumental in my early years of College and developing a critical mind. She listened to my goals and was very helpful in my decision to go into this line of study.

These professors have all been great role models and have gone above and beyond on many occasions to help me. I hope that I can follow their examples going forward.

Finally, I would like to thank my mom, Sandrina Parsons who made sacrifices so I could devote adequate time to this research. She encouraged me to set goals and aim high. Thanks to everyone for giving me this opportunity. 


\section{TABLE OF CONTENTS}

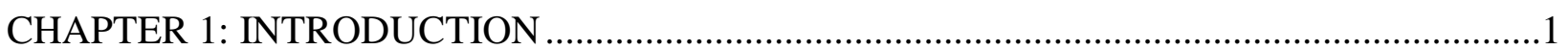

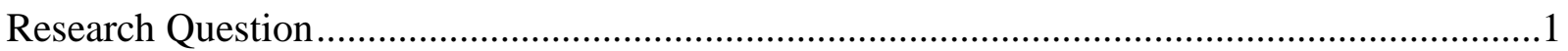

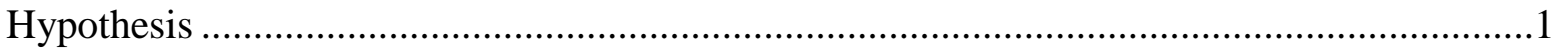

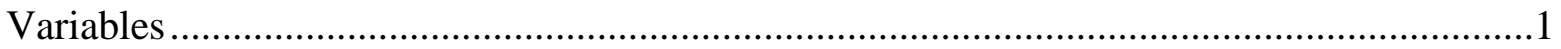

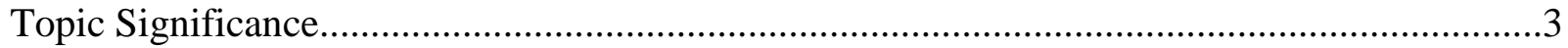

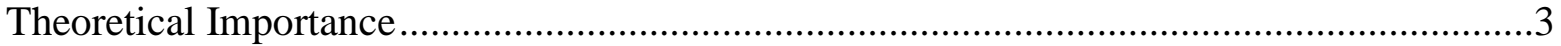

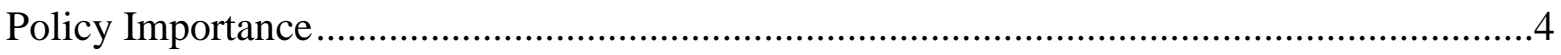

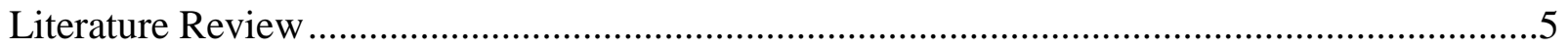

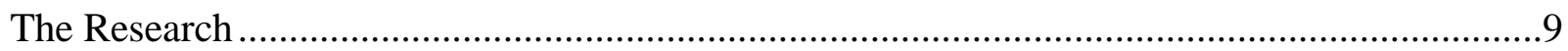

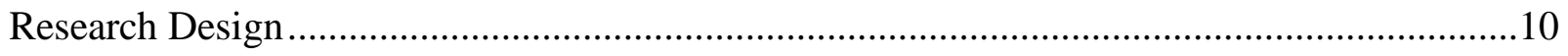

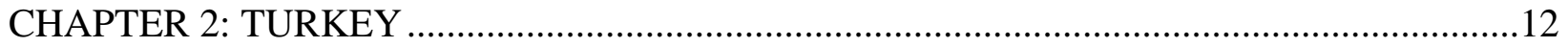

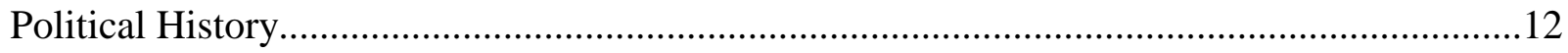

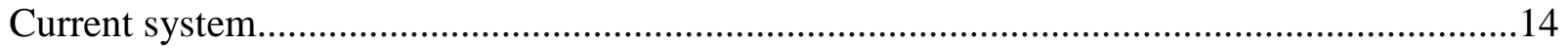

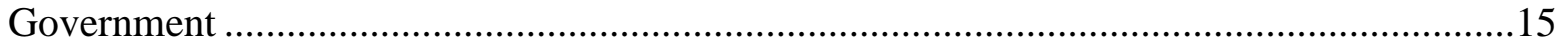

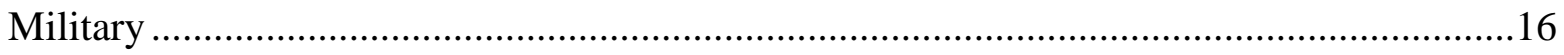

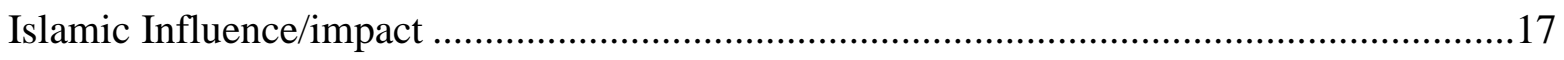

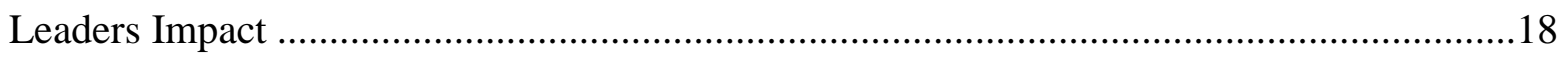

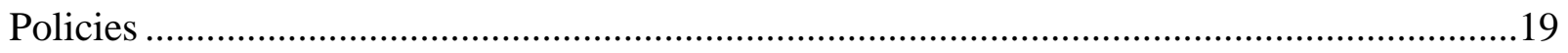

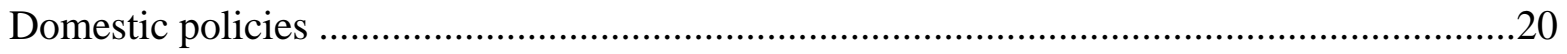

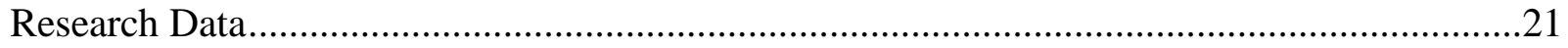

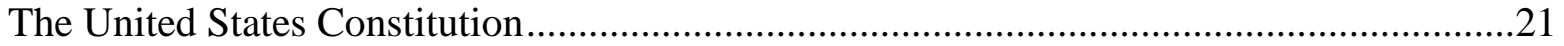




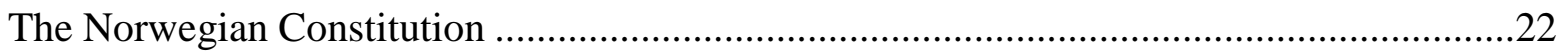

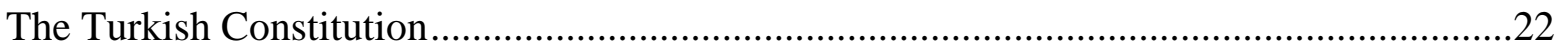

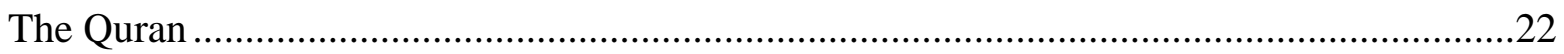

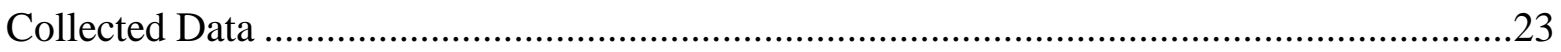

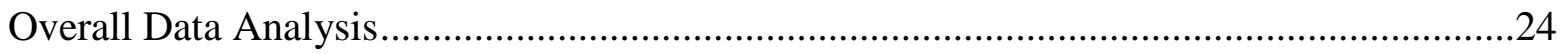

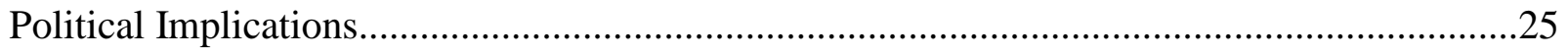

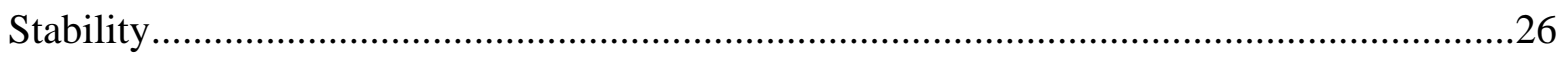

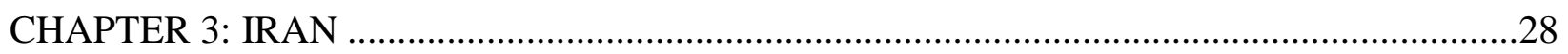

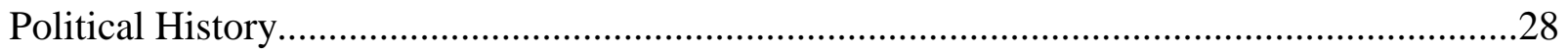

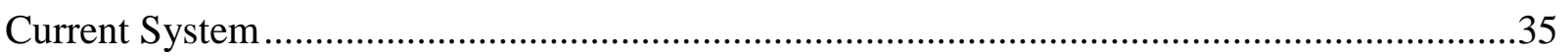

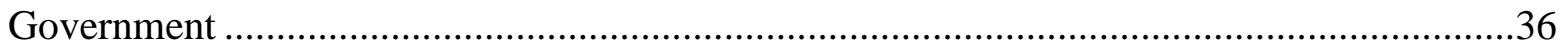

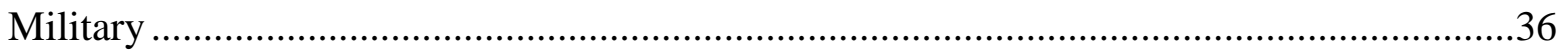

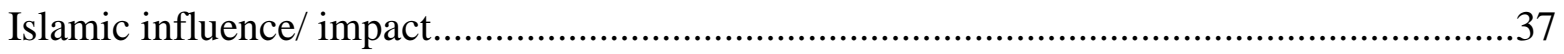

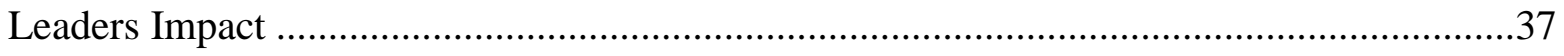

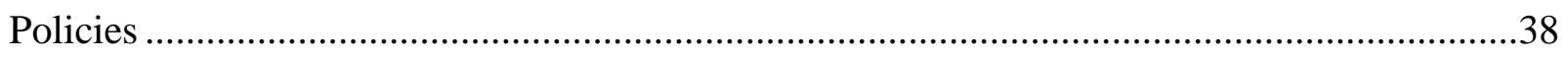

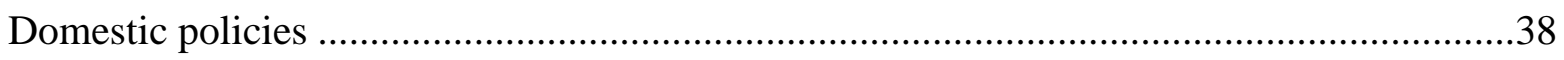

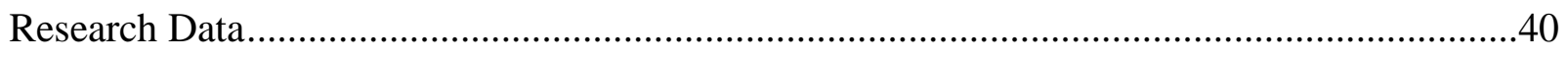

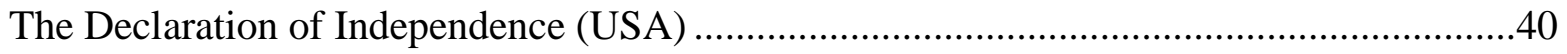

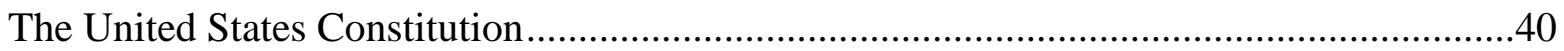

The Norwegian Constitution ….............................................................................41

The Iranian Constitution .................................................................................... 41

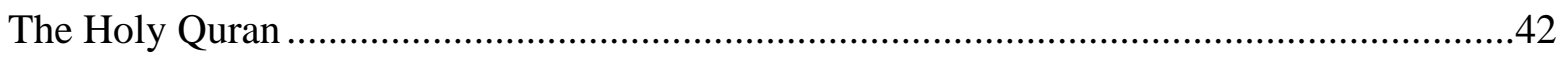

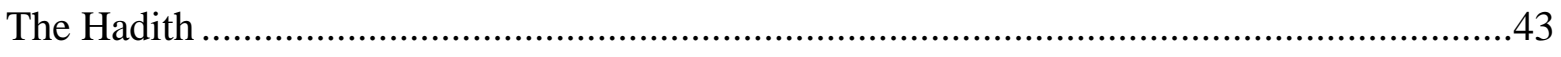




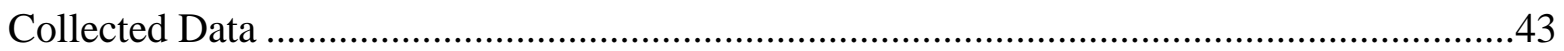

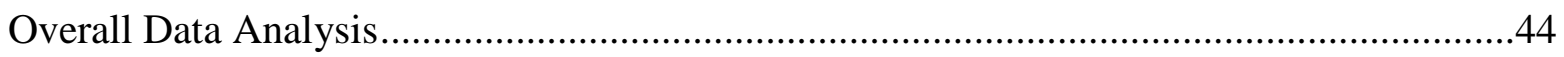

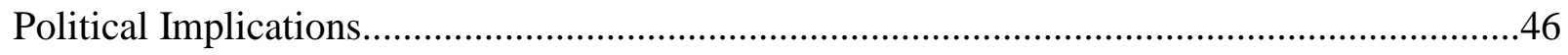

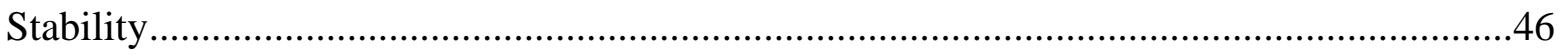

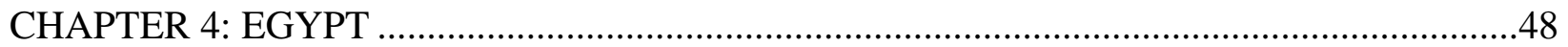

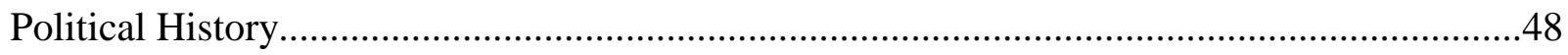

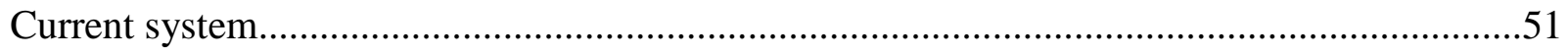

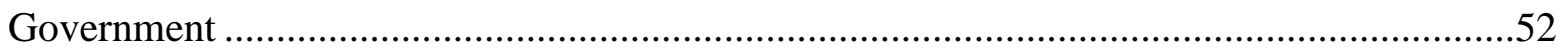

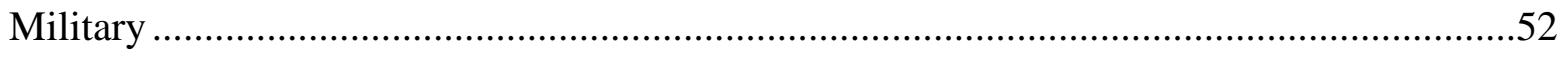

Islamic influence/ impact......................................................................................53

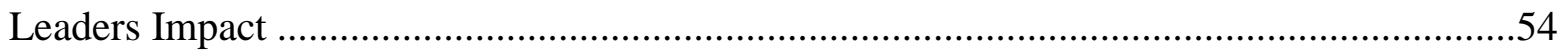

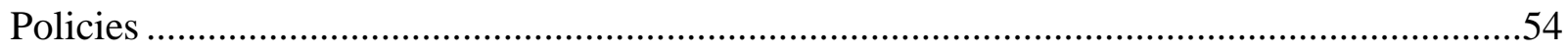

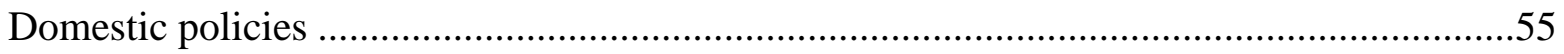

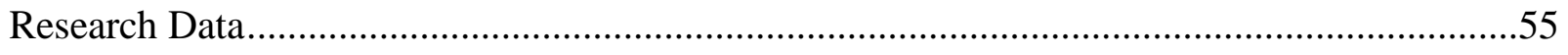

The United States Constitution ...............................................................................56

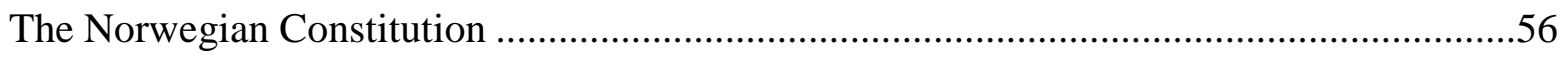

The Egyptian Constitution.......................................................................................5

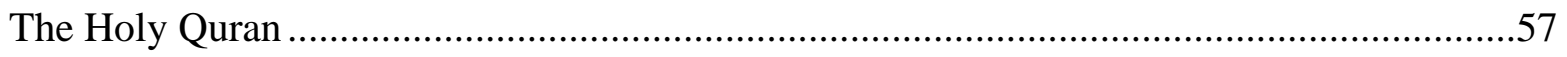

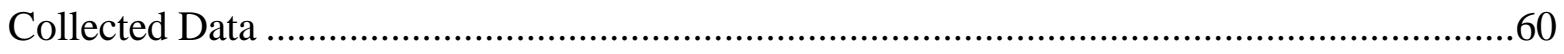

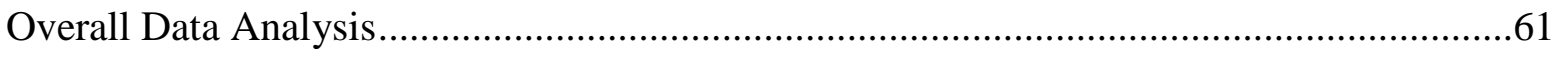

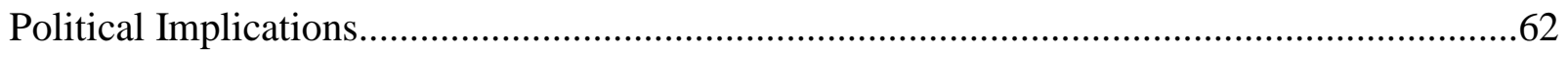

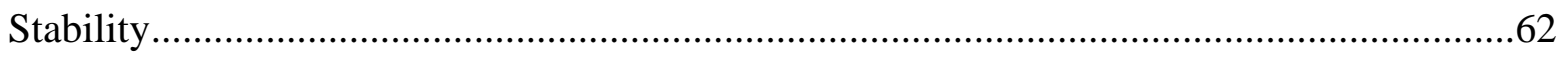

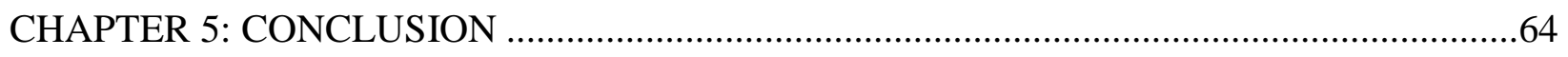




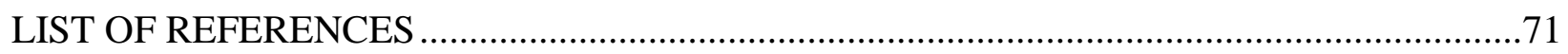




\section{LIST OF TABLES}

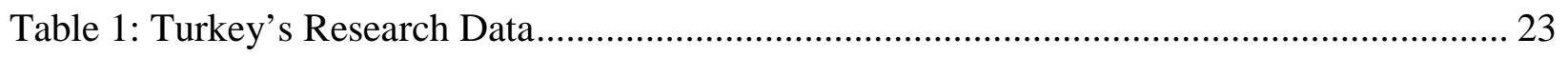

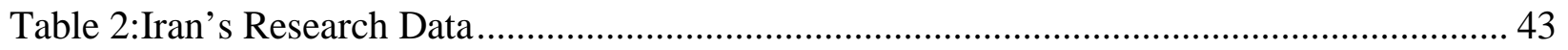

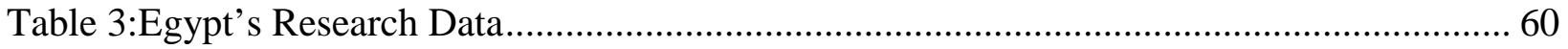




\section{CHAPTER 1: INTRODUCTION}

\section{$\underline{\text { Research Question }}$}

The thesis is a comparative study between Political Islam and democracy. The study will look at how both affect the Middle East. This study will try to answer 'Is it possible to have Democracy in Political Islamic?' A few main questions that would be considered are: Does political Islam encourage violence or crisis, while democracy encourages peace? How do the ideologies of political Islam impact the politics of the Middle East? How does the political system of Democracy affect the politics of the Middle East? Is Political Islam and Democracy compatible? The research and analysis on these questions and more, will give the data needed to answer the thesis question.

\section{Hypothesis}

Secular nations using constitutions, having majority rule by the people's choice, that give rights and lawful freedoms to citizens, are more likely to be democratic, than nations that include religious laws in their governmental system and administration.

\section{Variables}

The independent variable for the research is Political Islam through the main characteristics of states that are of high importance in the Middle East. Therefore, when narrowed, the independent variables in this research are the political ideologies of Islam, the 
various leaders in the Middle East, the ideological sects in these Middle Eastern regions and the policies. The dependent variable is democracy. The research will look at the way the ideologies compare to the views of democracy and if democracy can survive in each country. The effects of both variables on the global stage will be thoroughly looked at, and discussed throughout this study.

Using these two variables, Political Islam and Democracy, this study will try to assess if it is possible to have democracy in an Islam State. To do this, the study should give solid analysis and results. Democracy and Islamic rule are both systems used to govern. They both have rules that are laws or practices that are expected to be followed. Therefore, the opportunity to perform a comparative study of the two, in order to draw a partial conclusion, is conceivable. Following this, a study of some of the states within the Middle Eastern region will be able to give concrete evidence of the principles followed by those states. This will broaden the data needed to complete the research. The variables intertwine because, while in different way and for different reasons, both are governing systems. They will be closely related.

It can be expected that the relationship between these variables would be inverse and have a negative correlation, since it appears that as political Islam grows, democracy weakens and vice-versa. The relationship should also be strong since through observation this pattern seems to be consistent. The research will seek to examine how both systems can benefit from each other and what they can do to understand each other. 
$\underline{\text { Topic Significance }}$

The relationship between Political Islam and democracy is significant because having a better understanding may be a positive move to addressing some of the conflicts the world faces today. The Middle East has a great Islamic population. It is also the habitat for some of the main terrorist groups that are a cause of concern for the international community. In addition, with growing terrorists' issues, the Middle East seems to be plagued with conflicts. Another significant factor is that some nations in the Middle East may be gathering weaponry that may go against world regulations. Finally, and not of any lesser significant value, crucial resources that many nations of the world depend on are also located in the Middle East. This makes the study significant in analyzing the laws that govern the practices of Political Islam.

\section{Theoretical Importance}

Theoretically, Political Islam in Democracy is significant because both follow different laws and values aimed at creating the perfect governmental system. Political Islam follows a more traditional approach at politics and human liberties. For example, women's rights in the Middle East would be less than that of a more modern society that follows Democracy. Political Islam is a stratified society in which many people are separated into classes that have guidelines and limits on how they intermingle. The laws in political Islam are stricter and more punishable. Regular day citizens, in a higher class in political Islam, can carry out their own punishments to those under them. This can be in the form of whipping, or even mutilation. In Democracy, more civil rights are given, including freedom of speech for all genders. 
Democracy follows a more modern and less strict type of ideology. People of different classes/social bracket can intermingle on a daily basis and are free to express their opinions to those of a higher class. In a Democracy, only those whose job description can legally carry out punishments and usually these punishments are jail sentences and community service, are permitted to do so. These distinctions between Political Islam and Democracy are important to look at and understand because these can be the catalyst for why members of both systems seem to not like each other and may have problems coexisting. Many would call them opposites, with one following traditional and religious theologies and the other following modern, liberal and a controlled, justice-system type of theology. Understanding the difference can also allow these ideologies to overcome barriers.

\section{Policy Importance}

The policy importance of Democracy in Political Islam is that the structure tends to be a main factor in world peace. Since the Islamic movements have been expanding and are being viewed more as terrorist organizations than religious groups today, the policies that guide both the Islamic movements and a democracy can address conflicts and issues facing today's world. To Islamic regimes, the policies that they seek to enforce will bring a more solid and secure Islamic world. Democratic policymakers aim to find ways to increase human liberties within the Muslim world and the Middle East. These policies look at Islamic laws that do not favor humanitarian liberties as not being part of the current global system. This is important because the Middle East is developing a negative view on the world stage. The Middle East, as a region, 
does not have the same security and cooperation as any other region in the world. The Middle East is known for its civil wars and revolutions. This leads to a very violent atmosphere, which has probably caused the influx of refugees to other nations. Democracy is known throughout the world as peace-loving and nonviolent. It advocates diplomacy and talking conflicts out. As the saying goes, "Democracy never fights Democracy," this shows that Democratic nations tend to stick together and work together. The policy importance in this research is to try and find a middle ground for both ideologies that would incorporate policies from both sides to help improve both systems. This can help renew and build new relationships between the important oil producing regions of the Middle East and the rest of world.

\section{$\underline{\text { Literature Review }}$}

Islamic democracy has been a topic looked at in recent years. The research will use literature covering various eras and areas of political Islam and democracy. In addition to literature on the Middle Eastern region, literature specific to the nations in the case studies will also be used.

To understand the social situation in the Middle East, we will look at the book by James Bill and Robert Springborg published in 1999. The book is entilted 'Politics in the Middle East' and gives information on the development of Middle Eastern nations throughout history, as they develop politically. It will cover the social rankings and how these rankings developed traditional practices. James Bill and Robert Springborg will go over the leadership of the region, 
the implications of any change to the Middle East, the Middle East going into the future and how all of this will affect the global atmosphere. This book has specific chapters detailing each of the three nations chosen for the case studies in the research. ${ }^{i}$

The next text that will be referenced is the 2002 publication by John Esposito 'Unholy War: Terror in the Name of Islam' this book looks to examine political Islam and the belief of those that follow Islam and Islamic laws. It also addresses how radicals came to be and how their adverse feelings towards anything deemed modern and "American" became so intense. The teachings of Islam and the history associated with Islam will be thoroughly examined and used to make inferences. The literature in this book will be used to show the Islamic political views as written in the Quran and other Islamic teachings. ii

The third text referenced is the book "A history of Islamic Societies," by Ira M. Lapidus explores the beginning of many Middle Eastern nations and the way they developed not only as an Islamic society but also as a force in the global realm of international politics. Lapidus gives complete analysis and account of the factors that affected Middle Eastern societies. This literature will be used to further analyze understand the complete history for the Islamic case study nations. Using the history and facts one will better understand how certain decisions, ideologies, and policies of the case study nations will came to fruition. Lapidus's book will become a pivotal reference for the circumstantial information and missing data that makes the Islamic societies who they are today. ${ }^{\mathrm{iii}}$ 
The fourth piece of literature that would be looked at is a 2002 publication by Fatema Mernissi. The literature is titled 'Islam and Democracy: Fear of the Modern World'. The purpose of this literature in the research is to show some of the views from within the Middle East and more specifically the Muslim society. It will also explore some of the progressive groups which seek to defend democracy and change the Middle East from fundamentalism. This literature will be used to get a closer look of the relationship between political Islam and democracy. ${ }^{\text {iv }}$

Bernard Lewis' literature by the name of 'The crisis of Islam: Holy war and Unholy Terror', will give a factual account of the growth of Islam and how it inspired many events in history. It uses quotes from the Quran to support its facts on Islamic law. It will also use the pillars of Islam to explain, many of the actions taken by Muslims in recent times. In this book, Osama Bin Laden is analyzed and his actions were given a greater purpose and understanding. This book will be used in an attempt to understand why the conflicts are occurring in the Middle East and learn more about Islam. This will help give a better understanding of the fundamental differences and beliefs of those who follow Islam and those who hold democratic views. $^{v}$

The sixth literature that will be used in this study is the literature by Angel Rabasa, and Stephen Larrabee published in 2008 by the National Defense Research Institute 'The Rise of Political Islam in Turkey'. In this literature, the authors look at the history and impact of political Islam in Turkey. The authors look at why Turkey is secular now? And Why did the system 
change? The rise of Political Islam in Turkey also focuses on the leader's impact in Turkey and the change in the system from each leader. vi

In 2009 professor Ervand Abrahamian wrote a chapter on Iran, in the Advance Placement textbook, 'Introduction to Comparative Politics'. This 48 page chapter gives the complete history of the growth and development of the nation going back hundreds of years ago until recent times. His work will be used when isolating Iran for the case study. vii

The book 'A History of the Modern Middle East' Fifth Edition' was written by William Cleveland and Martin Bunton and published in 2012. It is included in the literature because it will firstly give another view of the Middle Eastern region and its early Islamic History. It will update some of the history of the previous literature. It also dedicates specific chapter to the three research countries of Turkey, Iran and Egypt. viii

A significant literature which is also the $8^{\text {th }}$ literature I will use in this study is the 'The Erdogan Experiment" by Deborah Sontag in 2013. In this article, Sontag examines the impact of the new leader in Turkey. The public reaction to this new leader and the policies that this leader puts forth will be a major part of this literature. Sontag analysis if the new leader will follow what he promised, to keep Turkey secular, or will he bring his religious beliefs into the government. ix

The final literature is the journal article by Kamilia Lahrichi in 2014 titled 'Political Islam Has Not Failed' in which Lahrichi examines the impact of political Islam in the Middle East. 
Lahrichi looks at the status of the different Islamic parties and analyses their impact. Lahrichi attempts to examine what is needed for Political Islam to work properly and efficiently and how it can succeed as governmental system in the Middle East. ${ }^{x}$

\section{The Research}

The literature shows that extensive studies have been done on the topic of Political Islam and Democracy. The literature exams Islamic laws and how they are viewed by the outside world. These laws would be looked at through their literal meaning as stated in the Quran. They would also be looked at through practical understandings which are seen from how they are used in today's time. The literature from Esposito will help cover how the current and modern Muslim societies came to be. The study will also look at the democratic concepts and compare them to actual happenings within the Islamic communities. Other literature will be used to give a background, support, and introduce new information on the Islamic societies of today and how they fit into the global atmosphere.

The study will give a brief general analysis of the Middle Eastern region. However, three countries will be used as case studies, and the research of those will cover a greater amount of details. It will briefly begin with each from when they were nomadic states. Then place high emphasis on politics of each from when they became Islamic nations. The research will include religion, culture and the political system. It will also give major political changes during the late $20^{\text {th }}$ and $21^{\text {st }}$ centuries. The gap in the literature that will be covered in my research is if there 
can be any democracy in political Islam. The literature will give a lot of information on political Islam, state actors, and the Middle East in general but not enough of it coexisting with democracy. My research will go over all aspects of political Islam and Democracy in regards to countries being studied and will go over the complete history of each to show how the contemporary politics of the countries came into being.

\section{$\underline{\text { Research Design }}$}

The thesis will be divided into three main sections which are the introduction, the research through case studies and the conclusion.

The Introduction will give a general overview of the research. It will include the research question, some of the history of the Middle East, and present the hypothesis to the research question. It will also address the reason that this area was selected and what is expected to be achieved through doing this topic.

The middle section, the research, will cover democracy in Islam. It will conduct case studies on three major countries in the Middle East. Each country would have many similarities since they are from the same region, however, they will have varied cultural background and population diversity, allowing for a wider study. The three countries of Turkey, Iran, and Egypt are each located on the continents of Asia and Europe, Asia, and Africa respectively. The areas that the research looked at in each case study were Political History, Current System, Policies, Research Data, and Political implications. Major sources that would be used to gain some 
information would be the constitutions of the three case study nations, the constitutions of two recognized democratic nations, and the Holy Quran as a guide to Islamic law.

The third section will be the conclusion. After investigating and analyzing the case studies, the conclusion will sum up the results, and evaluate if the hypothesis was correct. The research will collect data on the Middle Eastern leaders, and the policies that they implement. It will also measure the level of democracy, according to global norms, exhibited from three nations in the region, through conducting case studies. It will weigh the variables like military strength, religion and economy to see how they affect the level of democracy. After analyzing the data it will draw a conclusion of the role democracy plays in political Islam. 


\section{CHAPTER 2: TURKEY}

\section{Political History}

Turkey is a multicultural nation in the Middle East. This mixed culture is mainly due to the various people who settled in the nation, and the many changes in cultural leadership in the country's history. ${ }^{\mathrm{xi}}$ In its early years, Turkey had been fought over for one main reason; its strategic location. The nation is in an area that allows trading access to many other nations. Today, its location is still very important, not only for its trading advantages, but also because it is the connection or middle ground between Asia and Europe. Geographically the nation of Turkey falls on both continents.

The early history of Turkey, then Anatolia, shows the nation as being first inhabited by nomadic tribes. However, around 7,500 BC one of the earliest human settlements was established. This early sedentary lifestyle lasted for about 2000 years. Around 700 BC Anatolia, which was much larger in size than current day Turkey, was settled by the Greeks. The next thousand years would see the country change hands many times. The Greeks were first challenged by the Persians, who they had originally welcomed to live among them. Anatolia fell under Western Roman rule around 130 BC. Then in 285 BC the country again changed hands; this time to Eastern Roman leadership. In 330 AD, a new capital was established, in Anatolia, by the Roman Emperor. The new capital was named Constantinople. This new realm established the Byzantine Empire. 
In the $14^{\text {th }}$ century Anatolia fell to an Islamic tribe and became a part of the Ottoman Empire. Up until this time Anatolia, since it established a government, had been under the rule of Christians. The country's citizens comprised of a mixture of Christians, Jews, and Muslims.

The Ottoman leaders organized the government as a military system. Unlike the other nations around them, they welcomed everyone, regardless of race or religion. They encouraged citizens to live peacefully. They also allowed non-Muslims to join their military. These recruits had equal opportunity for advancement as the Islamic recruits.

The Ottoman Empire grew successfully for more than six hundred years. By World War I, the Ottoman Empire had spread over three continents, which were Europe, Asia and Africa. In the war, the Ottoman Military forces joined on the side of Germany, since the Allied Forces included Russia, one of the Ottoman's greatest enemies. Other European nations used this war, and the Ottoman's distractions to cut down the Ottoman's territory and their rule. The Ottoman Empire lasted for 623 years. ${ }^{\text {ii }}$

After World War I, France and Britain attempted to divide the Ottoman Empire into smaller states. While this was somewhat accomplished, the area that is now Turkey resisted the take-over, and the leaders were able to declare the country's independence on October 29, 1923. With this, the new nation of Turkey emerged. It was a lot smaller than Anatolia, but it was an independent nation, with a new name. The capital was also changed from Constantinople to Istanbul. ${ }^{\text {xiii }}$ 
Turkey was among the original members that signed the United Nation Charter in 1945. This showed an interest in keeping peace. The United Nations was the mediating law that would govern decisions that could affect the safety of any member state of the Union. ${ }^{\text {xiv }}$ While the efforts may have been a positive move for a good cause, by 2002 the literature was sending a different message. John L. Esposito wrote on the topic of democracy in the Middle East, that Islam and democracy are incompatible. ${ }^{\mathrm{xv}}$ For decades, the Middle Eastern region, which includes the nation of Turkey, has been involved in multiple civil, regional and international conflicts.

\section{Current system}

The Middle East, as a region, was stuck in a vacuum. This condition occurred because of the lack of a middle class existing during the mid-19th century. The growth of the Middle East was stunted. Political institutions, state structure, and humanitarian development were slowed and even in some cases stopped. The lack of a proactive middle-class/bourgeois stopped the loudest and more respected voice that can call for change. In a system like this, democracy cannot prosper or even be made. During this time, the Middle East had experienced many revolutions, military coups, civil wars, and wars among the different states. This was one of the bloodiest time periods for the Middle East. These aspects directly affected Turkey. Instead of the middle class leading the reins for modernization, the state took direct control of it in the early $20^{\text {th }}$ century. This was something new to the middle eastern region however, this was not new to Turkey since it adopted this system from the Ottoman Empire. Through the states' 
leadership, secularism and women rights were being adopted or forced on the Turkish population in the 1920 s. Political changes and reforms was coming in droves. ${ }^{x v i}$ Modernization and a more Democratic system was being forced on the Middle East through the hands of the states. ${ }^{x v i i}$

By 2015 since the destabilization of Turkey government from the modernization agenda, Turkey current government is secular and highly values the separation of state from government. This had led to problems when the citizens of Turkey believe that religion can come back into the state. ${ }^{\text {xviii }}$ Turkey right now is currently undergoing changes that do not support democracy since the coup attempt of $2016^{\mathrm{xix}}$. Turkey is one of the few majority Islamic secular states in the Middle East. This is to further the point that the traditional model of political Islam is preferred and more widely accepted in the Middle East. The cost to change to democracy and the cost to change the mindset of the majority of the citizens is a hard task to accomplish and pay. Turkey while being one of the few countries that overcame that task, is still plagued with insecurities about Islamic takeovers. ${ }^{x x}$ This hardened view from Turkey against political Islam stems from the years they followed Islam in the government and the radical change in their mindset.

\section{Government}

Turkey's current governmental model is one that is secular and parliamentary; it follows some democratic principles and has elections. The head of the government in Turkey is the 
Prime Minister and the head of the state is the president. The president is elected into office and the president has the right to pick the prime minister. For the prime minister to be fully approved they must also be voted for by the Parliament. Turkey, following the Western model has the 3 branches of parliament, the executive, judicial, and legislative branch, with all of them having checks and balances on each other. The current leading party of Turkey, while being an Islamic party, has been heavily criticized by the general public. Demonstrations against the views of the leaders and the way the country is heading have become an everyday occurrence in Turkey. ${ }^{x i}$ The people of Turkey prefer to remain secular and refuse to actively encourage Islam into their politics, rather keeping it to just their religion and personal life. This difference in ideologies and beliefs between the current governmental system and the general public have caused rifts, leading to the attempted coup of 2016 and general unrest in the current system. ${ }^{\mathrm{xxii}}$

\section{Military}

Under the Ottoman leadership Turkey was a military state and still has a strong military force, with the world's fifth largest peacetime military establishment, and a standing army boasting more than 800,000 . ${ }^{x i i i}$ The military in Turkey used to be controlled and financed by the rich and elite class. The rich had complete control of the Turkish military from the 1950s to late 1970. In the 1970s Turkey was plagued with political violence, in-fighting and assassinations. The Turkish military believing that the current system was harmful to Turkey and democracy decided to stage a takeover of the government in 1980. The coup was a success and the military then decided to rewrite and adopt a new constitution to make sure that democracy will be 
protected in Turkey. In 1983 the military of Turkey returned control of the government back to the citizens after finalizing the new constitution. ${ }^{x \text { xiv }}$ This also gave the military control of guarding Turkey's constitution to make sure its leaders stick to the values demonstrated and written in the constitution. ${ }^{x x v}$ The military still felt the need to intervene on many occasions after returning the government to the citizens. ${ }^{x x v i}$

The military and rich elites for Turkey have a long history of leading the country and enforcing their own policies. Complete control of the Turkish military has still not been given to the citizens. ${ }^{\text {xxvii }}$ The current military leaders in Turkey, under the secular parliamentary system, try to follow the rules and instructions of their government if they believe it is right. If the government is doing their job correctly and following the western system, the military will not intervene, but if the military feels that something can be done better, the Turkish military have shown that they are not afraid to step in. This undermines the current government institution and the beliefs of many of the population in Turkey; that being said, the military in Turkey have only intervened when they believe change is necessary and usually follow what is best for the country in their opinion. ${ }^{x x v i i i}$ Political dissidence like this, is however accepted and encouraged in Islamic law and beliefs. ${ }^{x i x}$

\section{Islamic Influence/impact}

Islam has had a huge impact on Turkey just like most of the Middle East. Turkey has allowed Islam into the government and followed the laws with the first Islamic leadership which 
began the growth of a majority Muslim population in the country. ${ }^{x x}$ A second impact was the expulsions of the Muslims from Spain in the early $17^{\text {th }}$ century. The Ottoman Empire welcomed the refugees, millions of Muslims came to Turkey. The location of Turkey has also put it in a position for growth, Turkey shares borders with Greece and Bulgaria on the European side, which is directly west of Turkey, on the Asian side Iraq, Iran, and Syria are located South of Turkey, and on the third side, directly to the East, it shares borders with Georgia and Armenia.

Historically, Turkey has always been a strategic point for trade in every way. This made the location important to many groups, but today it is especially important for the Islamic communities. Based on the predicament in Iran, Iraq and Syria it is difficult for Turkey to stay out of the issues since it shares borders with all of them. Not only is Turkey majority Islamic, but it also shares borders with other Islamic nations which are in conflict with each other. Turkey has currently shied away from political Islam, and has adopted a system of secularism.

\section{Leaders Impact}

The leaders of Turkey have always designed the national structure and policies based on their (the leaders) preferences. Forced to accept an Islamic way of life, the other religions were expected to wear specific identifying colors. Also, the names of the rulers called Sultans gave an idea of the type of government or rule that the citizens followed. Each Sultan had an identifying label after his name that gave an idea of his rule. Some of these labels were the conqueror, the 
warrior, the thunderbolt, the affable, the magnificent, the great, the grim, the god-like, and the lawmaker. These titles or additions gave an idea of the character and legacy of each sultan.

In the current system, like the leaders before him, Erdogan the devout Islamic leader of Turkey is fashioning his government to his standards. Contemporary leaders have been careful to keep the nation secular. So, while the system aims to promote individual preference of religion, the current system leans toward stronger Islamic ideals.

Erdogan does not show a bias against any of the other religious denominations, however, some of the policies he introduced do. One such policy is allowing the secular nation of Turkey to facilitate state run religious schools, that some students will be automatically placed in. ${ }^{x \times x i}$ Erdogan's program of bringing back religion into the government has become the main source of conflict in the region, where the general public are revolting and holding protest against his reforms. ${ }^{x \times x i i}$ It can be seen from this, that, with Erdogan in office, Turkey is once again shifting to an Islamic state. While the shift is relatively slow and he is still theoretically allowing Turkey to stay secular and is enforcing the ideas of a secular state and secular republic government, the policies Erdogan is promoting are not secular in meaning.

\section{$\underline{\text { Policies }}$}

Turkey has kept good communications with the western world and has allowed modernization into its government. In the early $20^{\text {th }}$ century radical Turkish leader, Ziya Gok-Alp sought to bring back nationalism to Turkey, after years of foreign rule. He did this through his 
three-stage modernization plan of Islamization, Turkification, and modernization. Later, around the mid- $20^{\text {th }}$ century, Mustafa Kemal 'Ataturk' expanded on the ideas of Gok-Alp. He stopped many of the Muslim ways, and switched Turkey to a more modern lifestyle instead. Since then Turkey has functioned as a secular state. However, after the second world war, there has been some activity by Islamic sects to return to traditional values such as wearing of veils for women and introducing religion back into the school system. Today, Turkey's president Erdogan has shown a lean toward re-introducing religion into the Government. ${ }^{\text {xxiii }}$

\section{Domestic policies}

After World War I, the new Turkish government attempted to make the country a more modernize nation. They also aimed for some level of equality. One major change is that under the Ottoman rule, Turkish people were required to write from right to left following Islamic traditions. This has been changed to the reverse where writing and reading is done left to right, following the western model. Another change was to the wearing of Turbans and wearing of hats similar to those of the Europeans. Turkey concentrates on education and decent healthcare. The educational system for Turkey follows the western model of 12 year standard educational schooling, and then college or university classes. It has one of the best educational programs in the Middle East, in which almost all children are in schools and getting an education. There are no extra requirements to get into schools in Turkey and the schools are free for the majority of the standard educational years. ${ }^{\text {xxiv }}$ 
For Turkey's health program, they also follow the western models. ${ }^{\mathrm{xxv}}$ With the many health policies and programs being released in Turkey, the well-being of Turkish citizens overall is getting better. Every year more people are getting access to healthcare. Turkey has also become a major hotspot for fleeing refugees. These refugees migrate to Turkey for their accessible health and educational policies, which the refugees feel that it can help them to improve and regain some of their previous lifestyles before they made the decision to leave their home country. Turkey is, for the most part, accepting to these refugees since Turkey has had a history of having and being hospitable to people of many different religions and beliefs.

\section{$\underline{\text { Research Data }}$}

Data has been collected from 5 sources to obtain an answer to the research question "Is it possible to have Democracy in an Islamic State?" For democracy, the constitutions of Norway and the United States have been used. For Turkish law the constitution of Turkey has been used. For political Islamic influence the Quran has been used. To complete the study, data has been gathered from varied database sources that is relevant to the research.

Based on the turmoil within the countries leadership and military system and the attempted coups for this case study the research will focus on Turkey's governmental system.

\section{The United States Constitution}

Articles 1 to 3 of the United States Constitution outlines the three branches of government. The first is the Legislative Branch that makes the laws. The second is the 
Executive Branch that carries out the laws. The third is the Judicial Branch that interprets the law. These branches have limited powers that (i) avoid any one branch from becoming too powerful or self-serving, and (ii) allow the state representatives to continue to serve the constituents who elected them.

Amendment 12 of the constitution makes provisions for separation of power which further ensures no one branch have the capability to abuse power.

\section{The Norwegian Constitution}

In sections $B, C$, and $D$ of the Norwegian Constitution shows that the country has a parliamentary government with 3 branches. These branches are legislative, executive and Judicial. while the country has monarchy leadership they also have elections for high ranking officials.

\section{The Turkish Constitution}

In part one sections 6,7 , and 8 of the Turkish Constitution shows that governmental power is shared among three branches. These are the Legislative, Executive and Judicial branches.

\section{The Quran}

Three examples of Holy Quranic verses that give rights to forces, military or other, to fight their oppressors are 
2:193 And fight them until there is no persecution, and religion is only for Allah. But if they desist, then there should be no hostility except against the oppressors.

22:39-40, 39 Permission (to fight) is given to those on whom war is made, because they are oppressed. And surely Allah is Able to assist them

40 Those who are driven from their homes without a just cause except that they say: Our Lord is Allah. And if Allah did not repel some people by others, cloisters, and churches, and synagogues, and mosques in which Allah's name is much remembered, would have been pulled down. And surely Allah will help him who helps Him. Surely Allah is Strong, Mighty.

\section{Collected Data}

\section{Table 1: Turkey's Research Data}

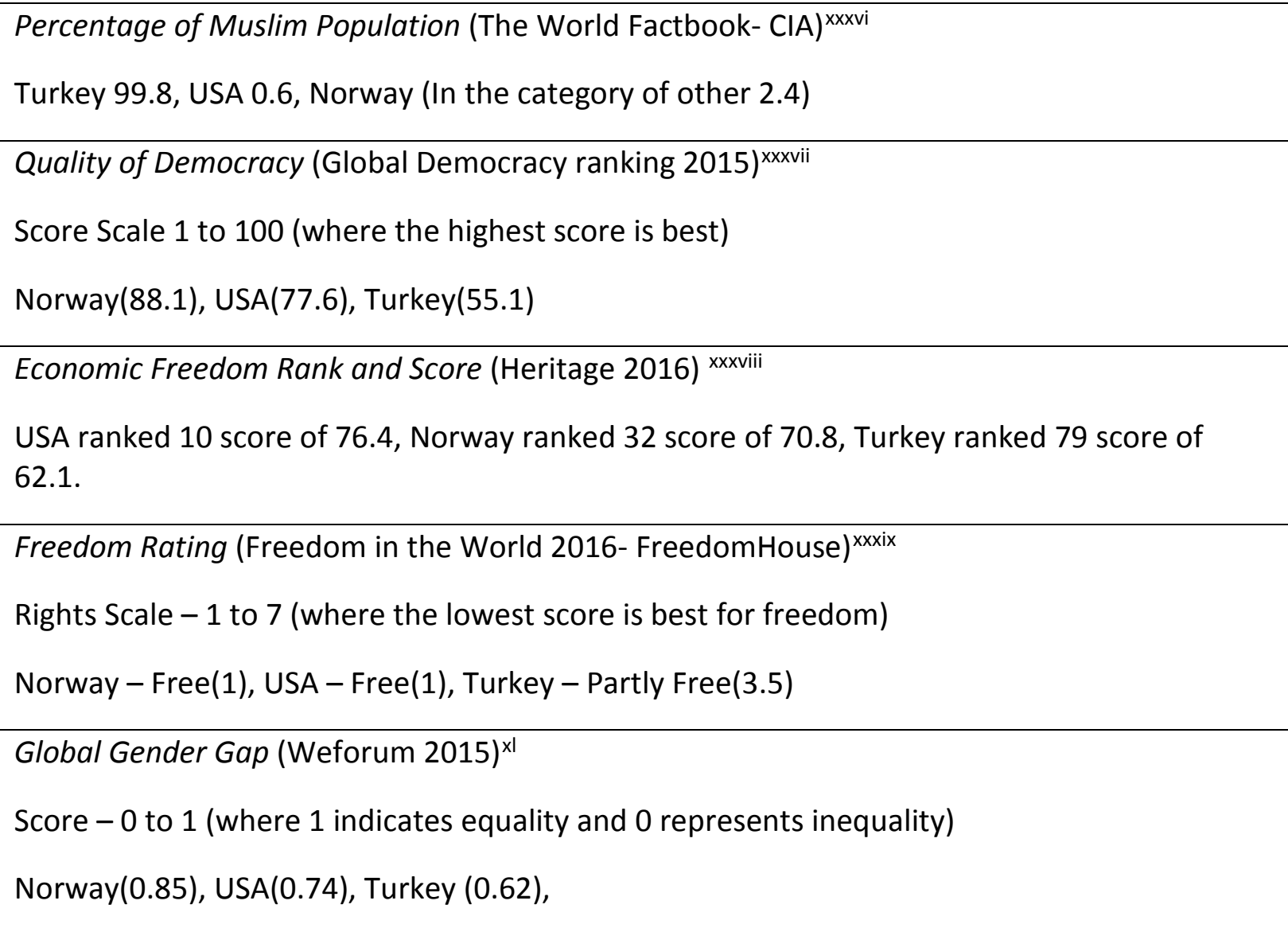


Military Strength (GlobalFirePower 2016) ${ }^{\mathrm{xli}}$

Ranking from 1 to 126 (where the lowest ranking indicates a greater military power)

USA(1), Turkey(8), Norway(38)

Percentage Population below the Poverty Line (The World Factbook- CIA) ) $^{\text {lii }}$

Norway (Not Listed), USA(15.1), Turkey(21.9)

\section{Overall Data Analysis}

On the whole, the three constitutions of the Muslim nation, Turkey and those of the Democratic nations of Norway and the United States of America, all seem to follow a

Democratic system. Each system has elections for top officials and give constitutional rights to the citizens. Although the constitutions have provisions for impeachment of the government, none of them gave any powers to the military for replacing a dysfunctional government.

However, based on Qur'anic law the military or any fraction has the right to oppose those who they believe are not following the will of Allah.

Turkey has a very high Sunni Islamic population. It is partly free but has a 55.1 percent quality of democracy score. The population below the poverty line is a lot higher in comparison to that of the United States. Turkey's Global Gender Gap score for 2016 was .62 which is a vast difference to that of the democratic nations. However, Turkey falls high on the Military Strength Ranking Scale. This places the nation among the top military powers of the world. 


\section{Political Implications}

The rise of modernization in Turkey and the shift to a secular state that follows a parliamentary system can be attributed to Turkey's reliance on following the Western state systems and infrastructure. Political Islam and parties that follow Islamic beliefs have faced a lot of criticism in Turkey. Turkey's military, leaders, and general public strongly believe in following the Western political system and that this is the right way to advance, but by doing so, Turkey has met many problems. Turkey has rejected many beliefs of political Islam and has isolated any leader who follows Islam. The change to a democratic system has called for many new changes that the Middle East might not be ready for. Since secularism and democracy are not fully supported ideas in the Middle East full integration of these ideas in any government and state would be hard, the people will need time to adjust and some may feel hurt by the change.

This new system is against the traditions that the Middle East was born under and while it is moderately working in Turkey, we can see that in order for it to work the people needed to adjust to the more modern system. Many Turkish citizens refuse to allow those that do not share secular views or beliefs into office, and with the rise in anti-American settlement in Turkey, a clash of ideologies may come forth. Right now, in Turkey, peaceful coexistence with political Islam and democracy is mediocre but successful.

Most of the coups have been actions taken by the military against the leader they believe to be corrupt. The most recent attempt of coup in Turkey was the coup of July 15, 2016. This coup was an attempt by a faction of the Turkish armed forces to take over many key areas 
in Turkey including roads and state buildings. The individuals who attempted the coup stated the decline in secularism and democratic policies in Turkey as one of the reasons for the attempted coup. This coup would ultimately end as a failure when the remaining military and the citizens chose to side with the current government and President Erdogan. The result of this attempted coup was the increased restrictions placed on journalist and the opposition party in Turkey. President Erdogan was able to arrest many individuals who were against his administration on the basis of treason or planning treason. This gave even more power to the President of Turkey.

\section{Stability}

Economically, and politically Turkey is a stable nation. It is making profits through its weapons production industry. It also has a government with strong central powers while still maintaining a strong military. The overall economic freedom index of Turkey is 62.1, which means it is moderately free. Turkey's freedom from corruption score is 45.0. Its labor freedom score is 48.6. ${ }^{\text {xliii }}$ Turkey's civil liberties score is 4 and its political rights score is 3 giving it a Freedom rating of a 3.5.

The government of Turkey encourages education for all, and a strong program that sticks to freedom of speech. While Turkey has had its share of corruption, it's still on the path of becoming an established democracy following the Western model. The secular state of Turkey is steadily improving its flexibility to other religions in terms of holding official positions. This is a 
marked change for improvement. The Turkish government is usually accepting of refugees but with the rise in refugees many problems have come to Turkey, such as job market problems, housing problems, and the rise of criminal activities with some of the refugees.

The immigration problem and the current political reforms that are occurring every day in the country are all points of worry for Turkish citizens. The threat of bringing back of religion into the state and the reversion of secularism ideals by leaders of Turkey is another problem for the nation. Despite all of these problems and points of worry, Turkey seems to be in general a stable country that is on the rise. However, based on the coup attempts and the exercising of Unitarian leadership powers, Turkey is not as stable as a progressive nation should be.

While it may appear that Turkey follows a democratic system of Government, by the way the system is organized and the process for electing officials, it also appears that if major laws of the Quran are followed, they will be in direct opposition of democratic guidelines.

With each new leader, the views of the nation are changed to fit that leader. This shows that, in Turkey, the person who takes the highest position in office actually has a lot of the power and can make decisions that affect the country. The shift in the current system, and the threat of the return of religion in the system, can also be an indication that there could be use of Islamic laws. Some of these laws will threaten democracy. 


\section{CHAPTER 3: IRAN}

\section{Political History}

The Republic of Iran, also named Persia is located in the Persian Gulf. Historically, as with all cultures, the first people to settle in Iran, thousands of years ago, were the nomadic tribes. Around $800 \mathrm{BC}$, the Medes and the Persians settled in the land. From then, the nation has been ruled by various Empires or governmental systems. One aspect that remained steady for about 2,500 years, until 1979 was the monarchy government. Each had variations in its system, and became more specific a Monarchy, Feudal Monarchy or Theoretical Monarchy. Each leader attempted to advance the country as it grew.

One of the first notable rulers of Iran was Cyrus the Great. He ruled around 559BC. He used common sense to know that he will be better served, if he did not instill fear and force on his subjects. He proved his political greatness throughout his rule. The first great capital of the Persian Empire established by Cyrus the Great was called Pasargadae and it was located in modern day Iran. ${ }^{\text {liv }}$ In those days, nations declared war and conquered other lands. This expanded the size of the nation. Usually, once a land is conquered, male prisoners were painfully executed. Women prisoners were raped and sold into slavery. Children were also sold into slavery. Cyrus the Great changed all of this when, after a war and great conquest, he freed hundreds of thousands of Babylonian prisoners and their Jewish slaves. He allowed all his 
people and his captives to keep their own faith. He did not try to influence how they worshipped.

It is believed that Cyrus the Great was the first person to practice democracy and therefore, Persia would be first nation to have done this when he took that action in 539 BCE. Cyrus the Great may have been the first leader to exhibit human rights. He helped Persia to grow both through his successes in expansion and in development.

Darius the Great was another great leader of early Persian History. He extended the country of Persia by bringing together twenty-eight nations. The growing Persian Empire expanded from India in the East, to Egypt and Ethiopia in Africa; it also extended to Greece on the Mediterranean side, and to Russia in Europe. It was so vast an empire that Darius the Great established four capital cities. The royal home was located in one of the capitals, Persepolis, was is located in present day Iran Darius set up a governmental system aimed at keeping control of the empire while being fair to all. His reforms included government officials throughout the nation, the upper-class families paid taxes, and a standard monetary system that was recognized and accepted even in Europe. During his rule, the Persian empire expanded twice as much as it did with the previous two kings. It was a central trading location from all directions and could be reached from Europe, Africa and Asia. It grew economically. Persia become one of the most successful nations of the era. 
One significant change for Persia was around 224 AD, when religion began to spread. For centuries, the main religions of the empires were Zoroastrianism and Babylonianism. This era saw Christianity, Judaism, Hinduism, Buddhism and a few other additional religions emerging. Another important change was after the Islamic conquest of Persia, around 651 AD. Persia then became a predominantly Islamic state. Most of the Muslims practiced Twelve Shia Islam.

Although Persia, also Iran, has seen many empires, and kings all wanting to leave their name in the country's history, the leaders of the twentieth century have definitely secured a spot in history. Iran had gone through changes in territory and status. It was not the grand empire of the sixth century any more. It had seen its fair share of wars, and was now no longer the prominent country that it had been. Reza Khan, born in 1878, formed the last royal empire of Iran. He joined the military at a young age and quickly moved up the ranks. At that time the military was controlled by Russian officers. By 1921 Reza Khan had been able to oust the Russian heads and took control of the army himself. He was the Minister of War. ${ }^{x / v}$ At the time the king was basically a figure head, who left his office when he felt that a situation he may not be able to control was developing. Reza Khan then tried to lead the nation to becoming a Republic, but the people were not ready for that change and preferred to keep monarchy rule. By 1925, the parliament decided to get rid of the non-functioning king and proclaim Reza Khan the new king of Iran. He was now Reza Shah Pahlavi. This was the start of the Pahlavi Empire. 
At first, the people welcomed the new leader. He came with the promise to restore stability to the nation. Within his rule, Reza Shah also took the British to the world court. The British had established British Petroleum, which was monopolizing the economy of the oil rich nation. However, the World Bank gave the rights of the oil refinery to the British. This was a cause for tension between Reza Shah and the western world.

Reza Shah wanted to reform the country to a more westernized or modernized state. In order to do this, he had to use his power to enforce laws. He began by giving Islamic women a choice of whether they wanted to wear the mandatory veil or not. Men were ordered to shave their beards, and wear European clothing and head coverings. All criticism of his decisions was outlawed. He also had a ban on public demonstrations. However, he established schools because although he, himself did not have a formal education, he recognized the need for education. He also constructed roads and other developments aimed at bringing the country into the modern era. This was not readily accepted by the people. They saw the Shah as a dictator, who although he wanted reforms he was using the army and his power to force the country in that direction. ${ }^{x l v i}$

By 1941, and the onset of World War II, Iran's location made it important, as a go through point for European troops. The Shah did not want to enter the war. However, when the Russian and British armies came through, the Iranian army was unable to stop their progress. Under duress the Shah left for South Africa where he remained until his death in 1944. 
Iran was among the original nations signing the United Nations Charter. This agreement was intended to promote world peace and better international relations. However, this opened the door for many European nations to get in and take control of the Iranian Economy. ${ }^{\text {xlvii }}$ This move showed progression toward a more modernized nation. However, democracy was not fully embraced in Iran. It did not seem possible for Islam and democracy to co-exist. $^{\text {xlviii }}$

Reza Shah's successor was his 21-year-old son, Mohammad Reza Shah Pahlavi. Though no more than a boy, he was accepted by the people and the rest of the world as the new king. This Shah continued in his father's footstep wanting to lead the country to a more modernized stature.

In 1953, religious leaders were dissatisfied with the direction the country had taken. There was unrest among the people. The Shah fearing for his life fled to Baghdad and then to Italy. However, United States President Eisenhower joined with the British to return the Shah to Power. The shah was even more determined now to reform the country. He ruled with a stronger and firmer hand than his father.

In 1961, the Shah offered reforms to the citizens, in an attempt to make them more westernized or democratic. These reforms offered better land reforms, emancipation of women, better education, and healthcare. The reforms gave women the right to vote which was a very important and a historical step in the history of Iran. 
The Shah saw himself as the greatest king. Although the shah had been the king of Iran since 1941, he did not crown himself king until 1967. Here he named himself the greatest king or emperor and his wife the empress.

He wanted to follow in the example of Cyrus the Great. He did not force decisions on the citizens. However, in a very diplomatic fashion he was able to gain full control of the government and had the only say on all decisions, like his father before him. He was able to control the two political parties in the country. Eventually there was only one political party, the King's party. He continued the push for an educated people. He allied with the western states.

Still many people in the predominantly Muslim nation did not agree with the direction in which he was taking the country. To the Shah he was modernizing Iran. To the people he was attempting to change their culture. He was opposed by the religious leaders. At the same time the educated students now felt that he was not modernizing the nation but had achieved the rank of a dictator. They challenged that he was going against the constitution and did not give the parliament any say in the running of the government. According to the constitution of Iran, it should be the other way around with the king having the lesser say. To control the people a ban was placed on public protest; on one occasion the shah's military shot into the protesting groups, killing hundreds. The country was in civil turmoil. 
The Shah's greatest challenger was an Islamic politician, named Ruhollah Moosavi Khomeini, later called Ayatollah Khomeini. Ayatollah was a new title for the Supreme Leader. As others who criticized the actions of the shah, Khomeini was imprisoned for 15 months. Later, on his release, he was banished from the country. Khomeini lived in Iraq and from there continued to oppose the rule of the shah.

In 1976, the Shah lost more faith with the people when he changed the use of the Islamic Calendar, for the more ancient Persian Calendar. Khomeini, then almost 80 years was able to return to Iran and build support. This all climaxed in 1979 when the shah took his family and fled to Egypt after the people revolted against his government. ${ }^{x l i x}$ Iran is a nation where the population, although they may be victimized, will step up against unjust leaders.' Khomeini then declared the country an Islamic Republic to joyous applause and celebration, ending more than 2,500 years of monarchy rule. As this happened, the shah looked for refuge in the United States. President Jimmy Carter at first refused him entry, but when it was established that the shah was seeking medical attention, he was allowed to enter to receive cancer treatments.

The new Iranian government wanted the shah to be returned to face charges for injustices against the country. Many of his top officials had already been arrested and some executed. Carter used the argument that the shah was in the United States for medical reasons in order to refuse the request for extradition. He also reduced the United States personnel in Iran from around one thousand to under one hundred. Soon after, enraged students surrounded the United States Embassy in Tehran. The staff there had no choice but to 
surrender. Ayatollah Khomeini saw the hostages as bargaining chips. Amidst reports of mistreatment of the hostages, the United States continued to negotiate the release. There was one aborted rescue attempt. Even after the shah left the United States and was exiled to Egypt the hostages still were not released. Khomeini, who at first seemed willing to negotiate, became more demanding. It took fifteen months for negotiations to be finally completed. The Ayatollah would not release the fifty-two hostages until he received 79 billion of Iranian money frozen in banks around the world. The hostages were released less than two minutes after the new President, Ronald Regan was sworn into office.

\section{Current System}

As a republic, Iran had various governmental systems. There were slight democratic tendencies. Although there was a parliamentary system in force, the leadership functioned more like a religious and unitary state, with the Supreme Leader in full control. The position of Prime Minister was removed in 1989 by amending the constitution of Iran giving more power to the President. ${ }^{\text {li }}$ As evident by the handling of the situation with Mohammed Mossadegh, Iranian leaders did not accept opposition or a move towards increasing democracy. ${ }^{\text {lii }}$ It also shows that the government was able to be influenced by the Western leaders. ${ }^{\text {liii }}$ The Ayatollah was embraced by the nation. He was able to restore some of the traditions and culture that the citizens had been seeking. 


\section{Government}

Currently in Iran the Supreme leader, Ali Khamenei, has been in office since 1989. The President is Hassan Rouhani, who has held this office since 2013. The Speaker of Parliament is Ali Larijani who has held this office since 2008. The final notable position is that of the Chief Justice being held by Sadeq Larijani, who is the younger brother of the Speaker of Parliament Ali Larijani. Sadeq has held this office since 2009. Since Iran currently is a republic, all of these individuals have power and influence in the domestic policies of the nation. However, the person with the most influence in the domestic policies of the country and who heads all of the other branches of government is Ali Khamenei. As the supreme leader, he is the most commanding political authority in the region and has taken the approach of preserving the strength and survival of Islamic theocracy. liv

\section{Military}

Iran's military has shown that it takes charge in order to support the leader with whom they hold allegiance. They showed this on various occasions. One of the most significant is the removal and imprisonment of Mohammed Mossadegh. ${ }^{\mathrm{I}}$ In this instance, they supported the Shah of Iran, the Western leaders, and the CIA. A few years later they also showed their loyalty when they supported Ayatollah Khomeini after he took leadership leading to the Shah going into exile in Egypt. On more than one occasion, the military has shot into protesting crowds, who were violating rules that ordered no protesting. 


\section{Islamic influence/ impact}

The changes that Iran has gone through in order to either support Islamic traditions or modernization have created much turmoil in the country. Much of the conflict has been caused by those wanting to hold on to tradition. While some leaders have attempted to bring the nation to a more modern era, the resistance, by religious leaders has been strong. After many wars and battles and the $\mathrm{CIA}$ involvement with the banishment of Mossadegh, the citizens of Iran have started to adopt an anti-American and anti-western mindset. ${ }^{\text {Ivi }}$ This rejection came with greater emphasis on Islam and traditional values. This ideology and mindset was however threatened in the 1990s when the youth and women of Iran found greater importance in politics and a newfound fascination with Western ideology. The youths, around twenty to thirty years old, were rejecting these polices and electing officials that moved towards democratic and secularist policies. Ivii

\section{Leaders Impact}

In the past many Iranian leaders, have formed allies with the western leaders in order to bring Iran into a more modern era. However, history showed that many of those leaders were seeking their own interest and allowed a great deal of the citizens to become poor under their rule. While they did this, they also ruled with an iron fist. For many years Iranian leaders and population have emphasized Islamization and greater role for political Islam in their government. 


\section{$\underline{\text { Policies }}$}

When Khamenei took office he emphasized independence, following Islamic laws and justices, being righteous, and a nuclear program in his domestic policies. In his foreign policies, he has been a force of major opposition against the United States, he has stressed the fact of being independent of the United States and the way they (the USA) infringe on the sovereignty of other states.

\section{Domestic policies}

Iran current domestic policies have been anti-western and mainly anti-American but in recent years Iran and its leaders have entertained the possibility of a deal with the United States. With this, it is shown that cooperation between the United States and Iran is not impossible. It could be implied that in the future, bigger alliances and trade policies can be made to foster friendships between the two groups.

Through oil Iran's economy has been boosted, however, the social system allows for the rich to become richer and the poor to become poorer.

Iranian women have been struggling for equal rights. They do not get the same salaries or positions in the workplace as their male counterparts. During the Khomeini reign, it was made mandatory for women to return to wearing the traditional hijab. This has continued into current times. One parliamentary law dating back to the pre-1979 Islamic revolution requires married women firstly, to receive permission from their husband firstly to hold a passport, and 
secondly, to travel abroad. Iviii A bill proposed in 2012 and reported as approved in early 2013, stated that unmarried women up to the age of 40 needed permission from their guardian to travel. This guardian would usually be the father figure in her life. The bill was officially canceled in mid-February 2013 after numerous protests by women rights activists. ${ }^{\text {lix }}$ On the domestic front, there are also limits on the movements of women. One example is that females are not allowed to enter sport stadiums. Article 976 of the Civil Code of Iran grants citizenship to all children born on Iranian soil and to Iranian males. This article specifies however, children born to foreign males and Iranian females will be granted permanent residence instead. One area where women have made great strides in gaining equality is education. Women rights groups continue daily to gain equal rights for Iranian women.

One poll conducted by Zogby Research Services in late 2016 showed that $70 \%$ of Iranian citizens surveyed were dissatisfied with their government performance on advancing democracy and promoting personal and civil rights. At the same time $75 \%$ saw advancing democracy and protecting personal and civil rights as one of their most important priorities in 2015. ${ }^{1 x}$

In the 2017 elections, a notable omission was the question on women's rights ${ }^{\text {Ixi }}$. This may have stemmed from a poll taken close to the 2007 election, where the questions on women's rights were included and $89 \%$ of the Iranians surveyed felt that there was a great need for women's rights reforms so that men and women can be equal. "xii 


\section{$\underline{\text { Research Data }}$}

Again, data has been collected from four of the sources listed previously. Those are the constitutions of Norway and the United States of America, the Holy Quran and various Data Banks. In addition, three new sources have been added. These are the Iranian Constitution, the United States Declaration of Independence and the Hadith which carries the sayings of the Prophet Muhammad. After analysis, the answer to the research question 'Is it possible to have Democracy in an Islamic State?' will have greater accuracy.

One pressing issue of modernization, especially in democratic nations is equality. Examples of equality topics have been race, gender and class (e.g. the caste system). The research of this case study will focus on the topic that has been historically forefront in most societies. It will examine gender equality/ women's rights in Iran.

\section{The Declaration of Independence (USA)}

1776 - An excerpt from the Declaration of Independence states that all men are created equal. (N,B. 'Men' is used as a general term for all human beings).

\section{The United States Constitution}

1868 - The $14^{\text {th }}$ Amendment states that all United States Citizens are protected against discrimination, and that the states do not have the right to prevent citizens from obtaining these rights.

1920 - The $19^{\text {th }}$ Amendment granted women the right to vote. 


\section{The Norwegian Constitution}

Article 50 states that all citizen men and women acquiring the age of eighteen have the right to vote.

Article 97 states that all citizens are equal by law.

Article 109 states that it is a given right for all citizens to receive an education

\section{The Iranian Constitution}

Article 3 - Outlines the goals and duties of the government in serving the people through 16 subsections.

Sub-section 3 states free education and physical training for everyone at all levels, and the facilitation and expansion of higher education;

Sub-section 8 states the participation of the entire people in determining their political,

economic, social, and cultural destiny;

Sub-section 9 states the abolition of all forms of undesirable discrimination and the provision of equitable opportunities for all, in both the material and intellectual spheres;

Sub-section 14 secures the multifarious rights of all citizens, both women and men, and providing legal protection for all, as well as the equality of all before the 
law.

Article 20- All men and women receive equal protection of law in accordance with Islamic criteria.

Article 21- Specifically ensures the rights of women against discrimination in accordance with Islamic criteria.

\section{The Holy Quran}

$\underline{2: 223}$ (Marriage) gives the husband complete dominance over his wives including their bodies

$\underline{2: 228}$ (Rank) ranks a woman a degree below a man.

2:282 (Court testimony) states that the testimony of a woman is believed half as much as that of a man.

3:195 (Entering paradise) states Allah will give the same degree of forgiveness to men and to women who were persecuted or killed in his name

$\underline{4: 3}$ (Wife-to-husband ratio) states that a man can have up to four wives.

4:11 (Inheritance) states that the woman will receive half as much as the man in distribution

$\underline{4: 24}$ (slave girls) states that outside of marriage a man is permitted to take women to be kept as sex slaves. 
The Hadith (Sayings of the Prophet Muhammad)

"Seeking knowledge is mandatory for every Muslim."

"He who has a slave-girl and teaches her good manners and improves her education and then manumits and marries her, will get a double reward; and any slave who observes God's right and his master's right will get a double reward."

\section{Collected Data}

\section{Table 2:Iran's Research Data}

Percentage of Muslim Population (The World Factbook- $\mathrm{CIA})^{\text {Ixiii }}$

Iran 99.4, USA 0.6, Norway (In the category of other 2.4)

Quality of Democracy (Global Democracy ranking 2015)

Score Scale 1 to 100 (where the highest score is best)

Norway(88.1), USA(77.6), Iran (Not listed)

Economic Freedom Rank and Score (Heritage 2016) ${ }^{\mathrm{Ixv}}$

USA ranked 10 score of 76.4, Norway ranked 32 score of 70.8, Iran ranked 171 score of 43.5.

Freedom Rating (Freedom in the World 2016- FreedomHouse) ${ }^{\mathrm{lxvi}}$

Rights Scale -1 to 7 (where the lowest score is best for freedom)

Norway - Free(1), USA - Free(1), Iran - Not Free(6) 
Global Gender Gap (Weforum 2015) ${ }^{\mid x v i i}$

Score -0 to 1 (where 1 indicates equality and 0 represents inequality)

Norway(0.85), USA(0.74), Iran (0.58)

Military Strength (GlobalFirePower 2016)

Ranking from 1 to 126 (where the lowest ranking indicates a greater military power)

USA(1), Iran(21), Norway(38)

Percentage Population below the Poverty Line (The World Factbook- $\mathrm{CIA})^{\mid \mathrm{xix}}$

Norway (Not Listed), USA(15.1), Iran(18.7)

\section{Overall Data Analysis}

The constitutions of Iran, the United States of America and Norway all give equal rights to their citizens. The right to vote for women came at different times in history for each nation. In some instances, it was granted in stages by criteria. Most of the time it took the protests of strong-willed women to achieve this right. While making additions or amendments to the constitution may have been a slow process, currently voting is a given right in the United States, Norway and Iran. In all three nations, women, as well as men, have the right to elect their government officials. The constitution of Iran also lays these rights out as a goal and duty of the government in order to protect and secure its citizens.

Quranic verses seem to support a definite gender gap. They show that males have greater authority than the females by giving the husband permission to take what he wants from his wives whenever it pleases him. He also has the right to have up to four wives and take 
(not mutual) extra marital girls as sex slaves if he wants. Males are given twice as much inheritance, or considered twice as reputable as females in legal matters. Verse 2:223 clearly states that the man is a degree above a woman.

On the other hand, there are some Islamic teachings that do not seem to support a gender gap. Verse 3:195 states that Allah will give the same amount of forgiveness to both males and females who are persecuted or slain while serving him. This however, does not address the males or females who do not fall within this category. The Hadith, a collection of the teachings of Muhammad also shows where education should be for all. One verse however, although it supports the education of a slave girl, it seems that the education is limited to good manners to improve her.

Iran has a very high Shia Islamic population. It is not free and is not ranked on the quality of democracy scale. The population below the poverty line is extraordinary in comparison to that of the United States. Iran's military strength falls within the top 25 percentile of the world. However, the nation does show a distinct unfavorable rating on the global gender gap scale with a sizable break between men and women. The conclusion can be drawn that women in Iran are not as equal to the males, compared to other democratic nations in the world. 


\section{Political Implications}

Historically, the contemporary leaders of Iran have demonstrated that while it is easy to say there could be democracy in Islam, it is very hard to do. They have tried to encourage the people to follow more western traditions, but at the same time they use power and force to achieve this goal. Forcing traditional wear for women and ordering the men to change their traditional look is not democracy. Killing the innocent for speaking out is definitely not democracy. Islam is a way of life. In modern times, it is becoming more complicated as leaders try to mix modernization and democracy with traditions and Islam.

\section{Stability}

The overall economic freedom Index of Iran is 43.5, which means it is mostly unfree. Iran's Freedom from Corruption score for 2016 is (27.0) ${ }^{\text {Ixx }}$. Iran has a very low Freedom rating on the freedom index of a 6 out 7. This makes the nation 'Not Free' on the ranking scale.

Iran has been trying to keep tradition with modernization, however, this is putting a strain on ruling. There have been conflicts which have affected policies. The research shows that Iran has one of the lowest scores on gender equality. Women rights has been a global issue for nations developing and progressing into the modern era. In today's world, equal rights is one of the main characteristics for democracy. Based on the research, the Iranian constitution offers equal rights to women. However, some policies conflict with this law. Women in Iran struggle for equal rights for education, employment and even to visit some public places. In 
some cases, women over the adult age of 18 , still need the permission of their husband, father or next highest ranking male guardian in order to make important decision, such as traveling abroad. There are laws that set different criteria for children born to male and female Iranians when the other parent is foreign. These policies support the laws found in the Quran that give females half the rights of males. These laws are specific that the word of a woman is worth half as much of that of a male. In the case of inheritance, women will inherit half the distribution as the male sibling. These statistics, policies, practices, and Islamic guidelines as found in the Quran, show that it would take some time before Iran can become a full democratic nation, and be considered to have join the modern era, as some of the leaders in the past have attempted. 


\section{CHAPTER 4: EGYPT}

\section{Political History}

Egypt, the most populous Middle Eastern country is located on the continent of Africa.

The history of Egypt can be trace back to about 40,000 B.C. Egypt is the main country located along the Nile river. Throughout history the fertile soil of the river has been essential to the growth of the nation, making it a much sought after country.

In the sixth century B.C., the Egyptian nation was conquered by the Persians. Then again in 332 B.C. the country was captured by Macedonian leader Alexander the Great. Around 30 B.C. Egypt again changed hands and was under Roman rule for about 675 years. Under the Romans Egypt was no longer a nation, but a province of Rome. The Islamic conquest of Egypt was swift and efficient only taking about two years from 641 A.D to 643 A.D. ${ }^{\text {Ixxi }}$ This took the country into a period of Muslim rule, except for a small period when the country was ruled by the French. There were various Caliphates, dynasties, and finally the Ottoman rule lasting for at least 800 years. The British then took control of Egypt from 1882. ${ }^{\text {Ixii }}$ It remained the parent country until 1954. Egypt fought for its Independence from the British. Finally, after almost 2,300 years, Egypt was once again under native rule. It was an independent country with the official name 'Republic of Egypt'. At this point modern Egypt emerged.

Egypt's first president, Muhammad Nagrib, was placed under house arrest by Gamal Abdel Nasser, because the supporters of Nagrib, who were the members of the Islamic 
Brotherhood organization, had made an attempt on the life of Nasser. ${ }^{\text {Ixxiii }}$ Nasser had fought and was instrumental, basically leading the revolution for the country's independence from British rule. After the first election, he became the first Vice-President of the country. Nasser, then placed himself in office and became the second President of the country in 1956 . $^{\text {Ixiv }}$ He began introducing reforms toward building the new nation. His constitution included a clause that gave the president the power to appoint and dismiss ministers. Then he passed the law that gave women the right to vote for the first time in Egyptian History. In 1957 he established Egypt's first Parliament.

Nasser's attempt at building the country's economy came from land reforms and foreign affairs policies. Egyptian land was owned by very few Egyptian who held great amounts of the land. Nasser set limits on the amount of land any individual could own. In addition, he set up systems whereby farmers can work together with an aim for collective growth. Nasser ruled until his death from a heart attack in 1970.

The third president was Anwar Sadat. He was also a member of the revolutionary group that fought and gained independence for Egypt. He had been vice-president to Nasser. He was in power from 1970 to 1981 . He decided to use different foreign affair strategies than Nasser. He was successful in retaking Egyptian land taken by the Israelis during Nasser's reign. He became a hero to his people almost overnight. He was also successful in helping the Middle Eastern economy through development in the oil market. One of his main visions was to bring peace to the Middle East. ${ }^{\text {lxxv }}$ There had been much conflict with the Israelis occupying much of 
Arab land. Israel was at war with the Palestinians who claim that the land occupied by Israel belonged to the nation of Palestine. In 1979 he traveled to Israel for peace talks. The Arab world saw this action as treacherous. The other nations waged a boycott against Egypt. In 1981 while attending a parade, Muslim extremists, who were a part of the parade, assassinated him as he stood to salute them.

President Hosni Mubarak, the fourth president of Egypt, also left his mark on modern Egyptian history. He ruled Egypt for 30 years from 1981 to 2011.

Hosni Mubarak became the president after the assassination of President Sadat. Early in his presidency, he told Egyptians that he would continue the efforts of President Sadat. His main goal was for peace with Israel. This again put Egypt under the scrutiny of other Islamic nations. Many nations boycotted relations with Egypt. There were many calls for the country to return to a fully Islamic state. Many assassination attempts were made on the life of Mubarak.

After serving five terms in office, Mubarak wanted to serve a sixth term. He made it obvious that he planned to be president for life. Egyptians renewed their efforts to remove him from office. Under heavy protests, Mubarak was forced to leave office and hand over control of the nation to the military.

He was then arrested where he was charged with corruption. It was believed that during his years in office he had mis-managed national funds. His two sons were also charged. 
At the end of the trial, Mubarak and his sons were sentenced to three years in jail, without parole. The ex-president had also been placed on trial for the murder of more than 900 protesters in 2011. His sons and his top aides were also charged for this offence. It was believed that they oversaw the shootings of the protestors. In 2012 a court found Mubarak guilty and sentence him to life in Prison. However, that decision was later overturned, and the charges dismissed.

When he was ousted from office in 2011, Egypt was able to hold its first democratic election. There was much rejoicing among the Egyptian people, and in the surrounding Islamic states. Once again, the nation of Egypt was at a new beginning, after the thirty year tyrannical rule of Hosni Mubarak.

\section{Current system}

Egypt's current governmental system is based on republic ideals. At the head of the governmental system there is a President and Prime Minister. After every four years there will be an election for the seat of President. However, Egypt has had differing opinions in recent years of who should occupy the seat of President. In 2011 there were protests that banned and exiled President Hosni Mubarak from Egypt this was in hopes of returning Egypt towards democracy and ending his era of oppressive rule filled with corruption and violence. With the end of President Mubarak rule there was a political deadlock between many groups on the direction Egypt should go, with most favoring a democratic approach. The groups that all vied 
for control on the Egyptian government were the Islamist secularist, liberals, military, and radicals. This deadlock and struggle for control of Egypt continued for a little more than a year in which the military assumed temporary control.

\section{Government}

After that year, however, the Islamist Muslim Brotherhood won the election and President Mohammed Morsi took control in 2012. But, Morsi's rule was short lived and he was also driven out after protests and the military again took control. Morsi was taken out of office because of his policies and laws against the Islamist secularist and Christians. The people felt he was bringing religion back into the government and effectively hurting the individuals that are not following Islam and those who do not want religion in the government. The next president to take control of Egypt, who happens to also be its current president is President Abdel Fattah al-SiSi who won the elections of May 2014. President Abdel Fattah al-Sisi was the army chief of the military and now the President of Egypt. This leaves a fear in the heart of the people who believe the military will try to take permanent control of the government.

\section{Military}

The Military in Egypt has been a huge force in the country for the last few decades. The military has assumed control after each president they exiled from the country. With the current president being the former army chief in the Military, many fear that the Military has 
taken control of the government. The Egyptian Military has helped in the ousting of many presidents and has tried to maintain a secularist ideology.

Every administration that has taken power since Egypt gained its independence has left its mark in history. A political study of Egypt was significant to this research. Egypt is a considerably new nation compared to the others in the case study. With its few rulers it allowed for a more detailed study of the role democracy played in forming the country. Once all outside rule was over, Egypt held it first election and began reforms that would help to modernized the country. While modernization does not automatically mean democracy, democracy is the accepted norm for the most efficient political world. Egypt has been promoting democracy and creating laws stemmed at democracy, however, the practices of the leaders show them all being closer to tyrannical ruler-ship. As they strived to join the rest of the world in more democratic views they had to also consider the people, and their positions as leaders in the Arab world. Egypt showed the most promise at becoming a democratic state. However, as seen in the case of President Sadat, if this should happen, it could be fatal to the leader. ${ }^{\text {Ixxi }}$

\section{Islamic influence/ impact}

Egypt has been a nation that has been plagued with political unrest as far back as could be remembered ${ }^{\mid x x v i i}$. Not only do the citizens show their disapproval where political issues and modernization is concerned but the surrounding nations have also taken strong actions against 
Egypt. Egypt has been faced with sanctions and boycotts based on their preference of alliance. While Egypt is among the newer states in the Middle East to have gained its independence it still faces conflicts and revolutions. These conflicts are from Islamic groups based on their preference of leadership. One leader, President Anwar Sadat was assassinated because his citizens felt he had made too close an alliance with Israel and the United States. Each leader in Egypt has tried to make Egypt into their image of what the nation should be. This has caused Egypt and Egyptian leaders to have been labeled as corrupt.

\section{Leaders Impact}

Egyptian leaders are probably among the most well known leaders in the Middle East, beginning with Nasser who brought nationalization back to Egypt. Also well-known are Anwar Sadat who tried to bring western culture into Egypt and Mubarak whose party of the Muslim brotherhood took advantage of Egypt. Egypt has had corrupt leaders who have sought their own benefits above those of the regular citizens. They have also had good leaders who were persecuted for trying to help push the country further ahead.

\section{$\underline{\text { Policies }}$}

Egyptian leaders show that they want growth for the nation. They also show the willingness to accept western traditions, thereby coming into a more modern and democratic era. President Sadat reached out in an attempt to mend the issues between Israel and Palestine. For this he lost the support of his people and his life. Egypt, the once most influential 
nation of the Middle East has since lost the respect of many of its neighboring states. Although it has a parliamentary government, it seems to not have enough power to enforce a democratic system.

\section{Domestic policies}

Egyptian authorities have been enforcing laws that do not give the people rights and freedoms. According to Human Rights Watch, in 2016, there have been numerous arrest of protestors and journalists. Travel bans have been forced on, and assets frozen for human rights activists. Journalists have been allowed restricted rights. Internationally, Egypt has been placed among the worst violators of human rights. ${ }^{1 \times x v i i i}$

\section{$\underline{\text { Research Data }}$}

For this case study data, has been collected from the constitutions of Egypt, the United States of America, and Norway. As in the other case studies data will also be collected from the Holy Quran and various data banks. Egypt has been labeled as one of the greatest violators of human rights globally, with many instances of being reprimanded by Human rights organizations for their treatment of civilians. ${ }^{\mid x x i x}$ This study will concentrate on human rights issues within the nation, based on the laws of the country, the law of the Quran, the rights granted to the citizens in the constitution, and the practices of the administration. At the end of the case study the research would have additional evidence, and be closer in determining the answer to the question, "Is it possible to have Democracy in an Islamic State?" 


\section{The United States Constitution}

1891 - Amendment1 of the Bill of Rights grants these protections to all citizens Freedom of religion, speech, press, assembly, and petition.

Amendment 4- Right to basic privacy.

Amendment 5- Protects an individual from being deprived of the right to life, liberty, or

property.

Amendment 6- Right to fair and speedy trial.

Amendment 8- Rights against cruel and unjust punishments.

Amendment 14 section 1 - Protects an individual's rights to due process and equal protections of the law.

\section{The Norwegian Constitution}

Article 16 - Freedom of religion

Article 93- Right to life. Freedom against torture/cruel treatment and slavery or forced labor.

Article 95- Right to fair and speedy trial. Right to public trial.

Article 98- Protection against discrimination

Article 100 - Freedom of Expression, Freedom of conscience/opinion/speech/thought, Freedom of press, Right to information, Right to public trial.

Article 102- Right to basic privacy, Guideline of evidence collection 


\section{The Egyptian Constitution}

Article 11: The place of women, motherhood and childhood

Article 52: Torture

Article 53: Equality in public rights and duties

Article 54: Personal freedom

Article 55: Due process

Article 57: Private life

Article 64: Freedom of belief

Article 65: Freedom of thought

Article 68: Access to information and official documents

Article 70: Freedom of the press

Article 73: Freedom of House

Article 96: The Right to Due process

\section{The Holy Quran}

2: 62- Surely those who believe, and those who are Jews, and the Christians, and the Sabians, whoever believes in Allah and the Last Day and does good, they have their reward with their Lord, and there is no fear for them, nor shall they grieve.

5:69- Surely those who believe and those who are Jews and the Sabians and the Christians whoever believes in Allah and the Last Day and does good - they shall have no fear nor shall they grieve. 
107:1-7, In the name of Allah, the Beneficent, the Merciful.

1- Hast thou seen him who belies religion?

2- That is the one who is rough to the orphan,

3- And urges not the feeding of the needy.

4- So woe to the praying ones,

5- Who are unmindful of their prayer! 1249

6- Who do (good) to be seen,

7- And refrain from acts of kindness!

\section{0:10-16-}

10- And pointed out to him the two conspicuous ways?

11- But he attempts not the uphill road;

12- And what will make thee comprehend what the uphill road is?

13- (It is) to free a slave,

14- Or to feed in a day of hunger

15- An orphan nearly related,

16- Or the poor man lying in the dust.

24:27- $O$ you who believe, enter not houses other than your own houses, until you have asked permission and saluted their inmates. This is better for you that you may be mindful.

6:151, Say: Come! I will recite what your Lord has forbidden to you: Associate naught with Him and do good to parents and slay not your children for (fear of) poverty - We provide for you and for them - and draw not nigh to indecencies, open or secret, and kill not the soul which Allah has made sacred except in the course of justice. This He enjoins upon you that you may understand.

\section{$5: 32-34-$}

32- For this reason We prescribed for the Children of Israel that whoever kills a person, unless it be for manslaughter or for mischief in the land, it is as though he had killed all men. And whoever saves a life, it is as though he had saved the lives of all men. And certainly Our messengers came to them with clear arguments, but even after that many of them commit excesses in the land. 
33- The only punishment of those who wage war against Allah and His Messenger and strive to make mischief in the land is that they should be murdered, or crucified, or their hands and their feet should be cut off on opposite sides, or they should be imprisoned. This shall be a disgrace for them in this world, and in the Hereafter they shall have a grievous chastisement.

34-Except those who repent before you overpower them; so know that Allah is Forgiving, Merciful.

8:12- When thy Lord revealed to the angels: I am with you, so make firm those who believe. I will cast terror into the hearts of those who disbelieve. So smite above the necks and smite every finger-tip of them.

48:29- Muhammad is the Messenger of Allah, and those with him are firm of heart against the disbelievers, compassionate among themselves.

24:2- The adulteress and the adulterer, flog each of them (with) a hundred stripes, and let not pity for them detain you from obedience to Allah, if you believe in Allah and the Last Day, and let a party of believers witness their chastisement.

\section{2:19-22-}

19- These are two adversaries who dispute about their Lord. So those who disbelieve, for them are cut out garments of fire. Boiling water will be poured out over their heads.

20- With it will be melted what is in their bellies and (their) skins as well.

21- And for them are whips of iron.

22- Whenever they desire to go forth from it, from grief, they are turned back into it, and (it is said): Taste the chastisement of burning

4:56- Those who disbelieve in Our Messages, We shall make them enter Fire. As often as their skins are burned, We shall change them for other skins, that they may taste the chastisement. Surely Allah is ever Mighty, Wise.

9:73- O Prophet, strive hard against the disbelievers and the hypocrites and be firm against them. And their abode is hell, and evil is the destination. 


\section{Collected Data}

\section{Table 3:Egypt's Research Data}

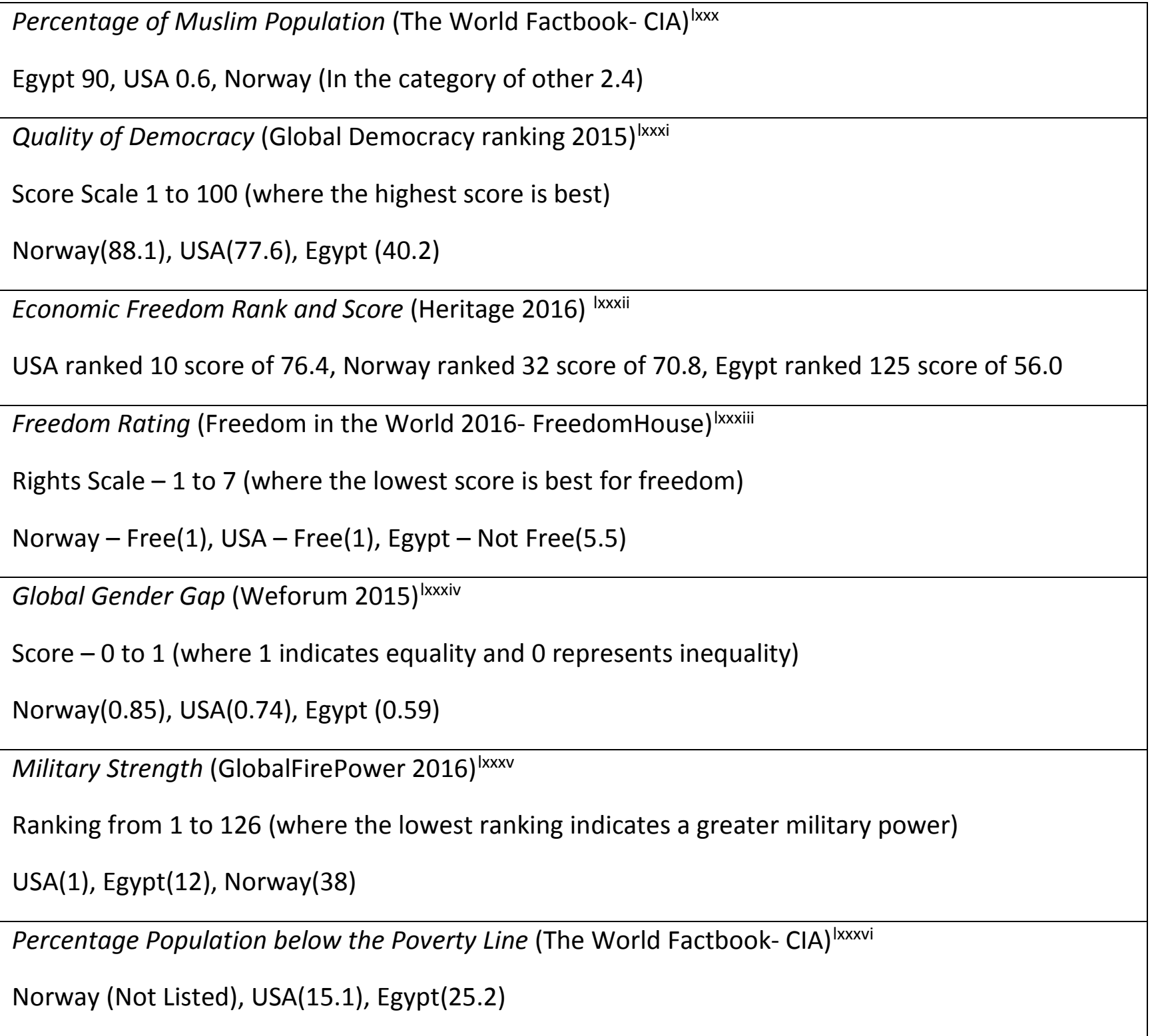




\section{Overall Data Analysis}

The constitutions of Egypt, the United States of America and Norway all offer basic human rights, freedoms and protection to their citizens and those within their territorial borders. These rights include freedom of speech, freedom of worship and freedom of assembly.

There are many verses of the Quran that show that believers should have no fear of persecution. They convince those who follow the ways of Allah that they will be doing what is right in the sight of Allah and all Muslims. However, there are just as many verses showing adverse outcome for the disbelievers of Allah. Some verses promote cruel punishment and even death. Disbelievers include those who oppose Islamic law, as it is laid out in the Holy Quran by Allah, and therefore create unrest. According to some verses of the Quran cruel and unjust punishment is acceptable in certain scenarios.

Egypt has a very high Sunni Islamic population. It has a 40.2 percent quality of democracy score. The population below the poverty line for Egypt is a lot higher in comparison to that of the other case study nations. Egypt Global Gender Gap score was .59. The overall economic freedom of Egypt for 2016 has a score of 56.0, which means it is mostly unfree. Egypt's freedom from corruption score is 37.0. Its labor freedom score is 51.4. ${ }^{\text {Ixxvii }}$ Egypt's civil liberties score is 5 and its political rights score is 6 giving it a Freedom rating of 5.5 on the Freedom House index. However, Egypt also falls high on the Military Strength Ranking Scale. 
Although Egypt has had the second least freedom rights score out of the three case study nations, its civil unrest has made this score significant. It is difficult for a country to coexist with democracy when it is in the midst of civil and regional conflicts. This mostly stems due to years of corruption in the government.

\section{Political Implications}

Egypt has struggled with other nations that believe that they, the nations, have a vision for Egypt's Islamic future. Those nations have attempted to stop Egypt from connecting with the western world. By doing this it also encourages the citizens of Egypt to fight against modernizations. The citizens would prefer to know that they can trade rather than be ostracized which is the ultimatum with which they have been faced. In return, Egyptian authorities enforce rules that go against the basic rights given in a democratic system.

\section{Stability}

Based on the research, the constitution of Egypt offers all civil liberties to its citizens. However, Egyptian authorities have placed limits on some freedoms and rights that citizens of democratic nations are allowed. The constitution of Egypt offers protections similarly to democratic nations against these human rights violations such as travel bans, limits on protests and wrongful incarcerations. While these policies may have been imposed to control pressing civil issues, they are still violations of civil rights due, and should be granted to the citizens. 
Many of those citizens have been law abiding, and should not be subjected to the enforced policies.

In this case study the Holy Quran offers protection to the believers of Allah. While it does not promote inhumane actions against believers, there no protection mentioned for disbelievers, except for those who convert.

A nation plagued with civil unrest, where laws and policies are implemented in order to satisfy its leaders is definitely not following a democratic system. 


\section{CHAPTER 5: CONCLUSION}

The object of this research was to determine if it is possible to have democracy in political Islam. The case study took a more detailed look at five specific areas. These were the political history, current system, policies, collected research data and political implications. From these main areas, it examined the geographic setting, the historical evolution, the socialcultural setting, economic conditions, the quality of life, political development, security/military conditions and the prospects for the future.

Many Islamic nations in the Middle East have adopted western governmental systems. Most have established constitutions that have the main characteristics of a democratic system. They have parliamentary governments where the citizens elect the leaders. However, based on the research, it is difficult for a full system of democracy to exist in the Middle East. The research conducted case studies on the nations of Turkey, Iran, and Egypt. While looking at key issues found within the region, deeper examination was given to the issue that puts the greatest risk on democratic ideals within each nation.

The country of Turkey is a predominately Sunni state; however, many other religious groups live in Turkey including Christians and Jews. The president is Erdogan who as a devout Muslim and believer in the Islamic religion, is slowly enforcing his beliefs back into the state and government. Many protests and demonstrations are held against Erdogan for his transgressions, but he is also praised by many of the Islamic leaders in Turkey who want to 
bring back religion into the government to follow the ways of the past. The research concluded that the government continues to lean toward incorporating religion in the secular state. If this happens it will be a move in opposition to what the country has established since the early $20^{\text {th }}$ century. It will also oppose the wishes of a great part of the population. The attempted coupes and loss of lives (especially those executed by both the military and the government), due to the military believing the country was being led in the wrong direction, would have all been in vain. Turkey is a multicultural nation. An Islamic system of government may therefore not be suitable for a great number of citizens. The aim to remain a secular state is being threatened in Turkey. One contributing factor is the surrounding Arab nations. This places Turkey in a position to follow more of the Islamic culture in order to fit in with the region. If a governmental body includes religious laws in a secular state then the wishes of the people will not be followed. In a democracy, the voice of the people is the loudest voice. A full democratic system is therefore threatened in Turkey. Some Quranic laws, if implemented, can lead away from this ideal.

Iran is a predominantly Shia Muslim nation that has seen political unrest for most of its existence. For more than a century, the Iranian leaders have had a pattern of single leadership rule. Iran has had a series of dynasties and Shahs who have shown, through history, that they are unable to accept challenges. Many of the Iranian leaders have used western influences to further their own prosperities. By doing this they have feinted a transition to democracy. These leaders ignited disapproval from the citizens, this then led to Iranian citizens preferring a more traditional and Islamic government. In Iran, the case study concluded that women did not 
receive equal rights. There are laws, policies and regulations, set directly for women, that made equal rights basically impossible. Many of these oppose the laws of the constitution. Women faced inequality in the workplace, their private lives, the lives of their children, and even in the movement to specific locations. However, these limits are quite normal in a predominantly Islamic State, where tradition is valued. Males are ranked above the females. Many parts of the Holy Quran, that reference women, support this open implementation of a gender gap.

The predominantly Sunni Muslim nation of Egypt, after fighting to gain its independence, was unable to get out of the complete control that the British had on the country. Like other Arab states in the region, Egyptians recognized that the economy was in the hands of foreign countries. Egypt's leaders attempted to be amicable with the rest of the western world, mainly the British, but this was unacceptable to other Middle Eastern nations. The nation of Egypt was basically ostracized from the rest of the Middle East. President Anwar Sadat was assassinated for the promises that he was making as he met with some of the western leaders. In the case study for Egypt, the research concluded that the limits placed on the rights and freedoms of the people were in direct violation of both the constitution and human rights. The civil and regional problems faced by the authorities forced them to implement restrictions in an attempt to gain firmer control. However, in order to enforce the restrictions, the authorities have been arresting citizens and activists who they believe pose a threat. Those arrested are usually exercising their given rights and freedoms, which is also acting within the law. The Quran does not encourage unjust treatment to the followers of 
Islam. Instead it encourages the oppressed to stand up and fight for Allah. It offers protection to those persecuted or killed while doing the work of Allah. However, it does not give any rights, privileges or compassion to disbelievers, unless they convert.

The research and evidence shows that political Islam and democracy are not compatible. Each time members of a Middle Eastern nation attempted to become more modernized and adapt a democratic system of government, it was met with opposition. This opposition has come in many forms. In the Middle East, it has been both civil and regional resistance. For Turkey, there has been an apparent lean towards becoming a more Islamic state by the leader. As seen in Iran, citizens have protested and rejected democracy. Egypt on the other hand, has had to face rejection from surrounding Islamic states.

The research question is 'Is it Possible to have Democracy in Political Islam?' To answer this, other questions had to be considered. The first would be to determine 'If it is possible to have democracy in an Islamic state?' The answer is yes, it is possible. The political system of a state is determined by its constitution. In examining the constitutions of Turkey, Iran and Egypt, it is the law that the government includes citizens, who have a say and vote for their top official, and who have rights by being granted civil liberties and freedoms. Therefore, the answer to this question of the research is that it is possible to have Democracy in an Islamic State'. While these nations may need to deal with internal and regional issues, they all have constitutions that promote democracy. If the provisions of the constitution are allowed, then it is possible to have Democracy in an Islamic State. 
The second question that should be answered is 'Is democracy and Political Islam compatible or can they even coexist?' While they could be compatible in some areas like offering protection to citizens, the constitutions do not specify believer or disbeliever, as does the Quran in some instances. It is one law for all, and the law of the constitution is the law of the land. There are many parts of the Quran that opposes the views of the constitution, such as equal rights, and cruel and unjust punishment. So, the answer to this is no. Political Islam and democracy are not compatible. On the other part of the question 'can they coexist'. The first thing to note is that they represent two different systems. Political Islam is an ideology, where there is a movement for growth in the Islamic states, through incorporating religion in the system of government. Democracy is a system of government, that offers power to the citizens. In order for the two to coexist, the people and the government must find common ground and coexist on balanced terms. As seen through the research there has been much conflict because of the split between of modernization and tradition. Modernizations offers a more democratic system that emphasizes control over one's life and decisions. Tradition offers values and practices that are conditioned into society that offer less individualized freedoms. The answer to this question again would be no, since it would be very difficult for political Islam which follows traditional ideology that is usually never altered, and democracy which follows a modern governmental system that could be changed through the opinion and the power of the people to coexist. 
“Is it possible to have Democracy in Political Islam?' After doing the case studies, the research had to be looked at from a different angle. This added a new aspect to the equation from the previous question, which is Political Islam taking the place of an Islamic state. In examining the research question, the evidence had to be looked at by its literal meaning. Political Islam is a movement that promotes incorporating Islam in a political system. Democracy is a system of government that includes the citizens of the nation having a say and civil liberties. Using the policies implemented in each case study nation the research concludes that some characteristics of democracy have been omitted or violated. Using Quranic verses the research concludes that Islamic laws can sometimes be misleading, or opposing to democratic views. The differences between the Islamic sects has contributed to the conflicts faced by the Middle East. The cultural differences between Muslims and the other religious societies have also been a source of conflicts. Most of all, the clash between progressing to modernization and keeping tradition has been the greatest issue. These issues were found in Turkey and Egypt, which are predominantly Sunni Muslim states, as well as in Iran a predominantly Shia state. In all case studies, the research has determined that it will take a lot of work and major changes for each nation to maintain a full democratic system.

The final conclusion of this research is that 'It is not possible to have Democracy in Political Islam.' They are incompatible and have conflicts co-existing. Evidence from the constitutions compared to the laws of the Quran support this conclusion. Collected data and policies implemented in the region that conflict with democratic views also support this 
conclusion. Collected research data on the conditions faced by citizens, including rights and civil liberties, gender equality, economic freedom and poverty percentage, the quality of democracy, and military influence, all give support to this conclusion. Therefore, it is not possible to have Democracy in Political Islam.

This research is important because knowing the main influence will affect the promotion and growth of Democracy in the Islamic state. Also, knowing the contributing factors to the constant conflicts in the Middle Eastern region will help with finding solutions to many issues, and analyzing if democracy in the governmental system will ease some of the tensions faced by the region. These are important factors in uniting the civil, regional, and international communities who interact with the Middle East.

This brings about two questions for consideration: The first being, "Can there be peace in the Middle East any time soon and can that peace come from a unified democratic system?" The second question is, "If allowed to happen, can religion in the governmental system of a democratic nation, like the United States of America, reduce the civil rights of the people?" 


\section{LIST OF REFERENCES}

Abrahamian, Ervand. "Chapter 12: A History of Modern Iran." In Introduction to Comparative Politics, edited by Mark Kesselman. Wadsworth Publishing; $5^{\text {th }}$ edition, 2009.

Aydin-Duzgit, Senem. "Turkey has given up on Democracy outside Its Borders, To." Foreignpolic., April 12, 2016. Accessed June 4, 2017. http://foreignpolicy.com/2016/04/12/turkey-has-given-up-on-democracy-outside-itsborders-too/

BBC. "Turkey profile - Timeline." Accessed February 13, 2016. http://www.bbc.com/news/world-europe-17994865.

Bill, James A. and Robert Springborg. Politics in the Middle East. New York: Pearson; 5 edition, 1999.

Campbell, David F.J. “Democracy Ranking 2015.” Democracy Ranking. December 15, 2015. Accessed September 20,2016. http://democracyranking.org/ranking/2015/data/Scores of the Democracy Ranking 2 015 A4.pdf.

Capezza, David. "Turkey's Military Is a Catalyst for Reform-The Military in Politics." Middle East Quarterly Summer(2009): 13-23. Accessed on June 12, 2017. http://www.meforum.org/2160/turkey-military-catalyst-for-reform.

Center for Human Rights in Iran. "Poll: 70\% of Iranians Dissatisfied With Rouhani on Democracy and Civil Rights." Iranhumanrights. January 21, 2017. Accessed June 20, 2017.

https://www.iranhumanrights.org/2017/01/poll-iranians-dissatisfied-with-rouhani-onhigh-priority-issues-of-democracy-and-civil-rights/.

Central Intelligence Agency. “The World Factbook.” Accessed May 8,2017. https://www.cia.gov/library/publications/the-world-factbook/geos/xx.html.

Cleveland, William L. A History of the Modern Middle East. Westview Press; 5th edition, 2012.

Davachi, Azadeh. "What Iranian Women Want-President Hassan Rouhani's second term is his chance to live up to Iranian women's hopes." Usnews. May 24, 2017. Accessed June 21, 2017. https://www.usnews.com/news/best-countries/articles/2017-05-24/in-iranwomen-want-rights-jobs-and-a-seat-at-the-table. 
Dehghan, Saeed K. "Iranian single women might need father's permission to go abroad." Theguardian. January 15, 2013. Accessed December 19, 2016. https://www.theguardian.com/world/2013/ian/15/iranian-women-fathers-permissionabroad.

Denny, Frederick M. An Introduction to Islam. Prentice Hall; $4^{\text {th }}$ edition, 2011.

Esfandiari, Golnaz. "Proposed Bill To Limit Iranian Women's Travel Reportedly Canceled." Radio Free Europe Radio Liberty. February 22, 2013. Accessed December 20, 2016. https://www.rferl.org/a/iran-bill-restrict-women-travel/24910177.html.

Esposito, John L. Unholy War: Terror in the Name of Islam. New York: Oxford University Press, 2002.

Freedom House. "Freedom in the World:2016." Accessed May 9, 2017. https://freedomhouse.org/report/freedom-world/freedom-world-2016.

Globalfirepower. "Military strength." Accessed September 25, 2016. http://www.globalfirepower.com/countries-listing.asp

Human Rights Watch. "Egypt: Events of 2015." Accessed July 1, 2017, https://www.hrw.org/middle-east/n-africa/egypt

Kamal, Kevin. "Education in Turkey." World Education News \&Review. April 4, 2017. Accessed June 10, 2017. http://wenr.wes.org/2017/04/education-in-turkey.

Kinzer, Stephen. All the Shah's Men: An American Coup and the Roots of Middle East Terror. New Jersey: Wiley; $2^{\text {nd }}$ edition, 2008.

Lahrichi, Kamilia. "Political Islam Has Not Failed." Palestine-Israel Journal of Politics, Economics \& Culture Vol.19, Issue 12 (2013): p160-163. Accessed October 10,2015. http://www.pij.org/details.php?id=1524.

Lapidus, Ira M. A History of Islamic Societies. New York: Cambridge University Press; $2^{\text {nd }}$ edition, 2002.

Letsch, Constanze. "Turkish parents complain of push towards religious schools." Theguardian. February 12, 2015. Accessed March 10, 2016. https://www.theguardian.com/world/2015/feb/12/turkish-parents-steered-religiousschools-secular-imam-hatip. 
Lewis, Bernard. The crisis of Islam: Holy war and Unholy Terror. New York: Modern Library; 1 edition, 2003.

Mernissi, Fatema. Islam and Democracy: Fear of the Modern World. New York: Basic Books; Reissue edition, 2002.

Rabasa, Angel, Stephen Larrabee, and National Defense Research Institute (U.S.). The Rise of Political Islam in Turkey. Santa Monica, CA: RAND Corporation, 2008.

Ray, Julie. “Iran's Election Brings Desire for Women's Rights Into Focus." Gallup. June 11, 2009. Accessed June 21, 2016. http://www.gallup.com/poll/120821/iran-election-bringsdesire-women-rights-focus.aspx .

Sadjadpour, Karim. "The Supreme Leader." Iranprimer. August 2015. Accessed July 3, 2016. http://iranprimer.usip.org/resource/supreme-leader.

Sontag, Deborah. "The Erdogan Experiment." NYTimes. May 11, 2013. Accessed October 8, 2015. http://www.nytimes.com/2003/05/11/magazine/the-erdoganexperiment.html?pagewanted=all

The Heritage Foundation. "2016 Index of Economic Freedom." Heritage. Accessed May 8, 2017. http://www.heritage.org/index/pdf/2016/book/executivehighlights.pdf.

Transanatolie. "Chronology." Accessed January 10, 2016. http://www.transanatolie.com/english/turkey/anatolia/Chronology/chronology.htm.

Weforum. “Ranking:2015." Accessed September 20, 2016. http://reports.weforum.org/globalgender-gap-report-2015/rankings/.

i James A. Bill and Robert Springborg, Politics in the Middle East (New York: Pearson; 5 edition, 1999).

ii John L. Esposito, Unholy War: Terror in the Name of Islam (New York: Oxford University Press, 2002).

iii Ira M Lapidus, A History of Islamic Societies (New York: Cambridge University Press; $2^{\text {nd }}$ edition, 2002). 
iv Fatema Mernissi, Islam and Democracy: Fear of the Modern World (New York: Basic Books; Reissue edition, 2002).

v Bernard Lewis, The crisis of Islam: Holy war and Unholy Terror (New York: Modern Library; 1 edition, 2003).

vi Angel Rabasa, Stephen Larrabee, and National Defense Research Institute (U.S.). The Rise of Political Islam in Turkey (Santa Monica, CA: RAND Corporation. 2008).

vii Ervand Abrahamian, "Chapter 12: A History of Modern Iran," In Introduction to Comparative Politics, ed. Mark Kesselman (Wadsworth Publishing; $5^{\text {th }}$ edition, 2009).

viii William L. Cleveland, A History of the Modern Middle East (Westview Press; 5th edition, 2012).

ix Deborah Sontag, "The Erdogan Experiment", NYTimes, May 11, 2013, accessed October 8, 2015, http://www.nytimes.com/2003/05/11/magazine/the-erdoganexperiment.html?pagewanted=all

x Kamilia Lahrichi, "Political Islam Has Not Failed," Palestine-Israel Journal of Politics, Economics \& Culture Vol.19, Issue 12 (2013): p160-163, accessed October 10,2015, http://www.pij.org/details.php?id=1524.

${ }^{x i}$ Angel Rabasa, Stephen Larrabee, and National Defense Research Institute (U.S.). The Rise of Political Islam in Turkey (Santa Monica, CA: RAND Corporation. 2008) iii.

xiiTransanatolie, "Chronology", accessed January 10, 2016, http://www.transanatolie.com/english/turkey/anatolia/Chronology/chronology.htm.

xiiiBBC, "Turkey profile - Timeline", accessed February 13, 2016, http://www.bbc.com/news/world-europe-17994865.

xivFatema Mernissi, Islam and Democracy: Fear of the Modern World (New York: Basic Books; Reissue edition, 2002) 62.

xvJohn L. Esposito, Unholy War: Terror in the Name of Islam (New York: Oxford University Press, 2002) 128.

xvi Ira M Lapidus, A History of Islamic Societies (New York: Cambridge University Press; $2^{\text {nd }}$ edition, 2002) 503. 
xviiJames A. Bill and Robert Springborg, Politics in the Middle East, (New York: Pearson; $5^{\text {th }}$ edition, 1999) 173.

xviiiDeborah Sontag, "The Erdogan Experiment", NYTimes, May 11, 2013, accessed October 20, 2015, http://www.nytimes.com/2003/05/11/magazine/the-erdoganexperiment.html?pagewanted=all.

xix Senem Aydin-Duzgit, "Turkey has given up on Democracy outside Its Borders, To," Foreignpolicy, April 12, 2016, accessed June 4, 2017, http://foreignpolicy.com/2016/04/12/turkey-has-given-up-on-democracy-outside-its-borderstoo/.

xxDeborah Sontag, "The Erdogan Experiment", NYTimes, May 11, 2013, accessed February 15, 2016, http://www.nytimes.com/2003/05/11/magazine/the-erdoganexperiment.html?pagewanted=all.

xxiKamilia Lahrichi, "Political Islam Has Not Failed," Palestine-Israel Journal of Politics, Economics \& Culture Vol.19, Issue 12 (2013): p163, accessed February 15, 2016, http://www.pij.org/details.php?id=1524.

xxiijohn L. Esposito, Unholy War: Terror in the Name of Islam (New York: Oxford University Press, 2002) 79.

xxiiiJames A. Bill and Robert Springborg, Politics in the Middle East (New York: Pearson; 5 edition, 1999) 180.

xxiv David Capezza, "Turkey's Military Is a Catalyst for Reform-The Military in Politics," Middle East Quarterly Summer(2009): 13-23, accessed on June 12, 2017. http://www.meforum.org/2160/turkey-military-catalyst-for-reform

${ }^{x \times v}$ William L. Cleveland, A History of the Modern Middle East (Westview Press; 5th edition, 2012) 278-279.

xxviJohn L. Esposito, Unholy War: Terror in the Name of Islam (New York: Oxford University Press, 2002) 141.

xxviiJames A. Bill and Robert Springborg, Politics in the Middle East (New York: Pearson; 5 edition, 1999) 185. 
xxviiiWilliam L. Cleveland, A History of the Modern Middle East (Westview Press; 5th edition, 2012) 281.

xxix Fatema Mernissi, Islam and Democracy: Fear of the Modern World (New York: Basic Books; Reissue edition, 2002) 27.

xxxBernard Lewis, The crisis of Islam: Holy war and Unholy Terror (New York: Modern Library; 1 edition, 2003) 35.

xxxi Constanze Letsch, "Turkish parents complain of push towards religious schools," theguardian, February 12, 2015, accessed March 10, 2016, https://www.theguardian.com/world/2015/feb/12/turkish-parents-steered-religious-schoolssecular-imam-hatip.

xxxii William L. Cleveland, A History of the Modern Middle East (Westview Press; 5th edition, 2012) 534.

xxxiii Frederick M. Denny, An Introduction to Islam, (Prentice Hall; $4^{\text {th }}$ edition, 2011) 330-331.

xxxiv Kevin Kamal, “Education in Turkey," World Education News \&Review, April 4, 2017, accessed June 10, 2017, http://wenr.wes.org/2017/04/education-in-turkey

xxxvJohn L. Esposito, Unholy War: Terror in the Name of Islam (New York: Oxford University Press, 2002) 80.

xxxvi Central Intelligence Agency, "The World Factbook," accessed May 8,2017, https://www.cia.gov/library/publications/the-world-factbook/geos/xx.html

xxxvii David F.J. Campbell, “Democracy Ranking 2015,” Democracy Ranking, December 15, 2015, accessed September 20,2016, http://democracyranking.org/ranking/2015/data/Scores of the Democracy Ranking 2015 A4.pdf.

xxxviii The Heritage Foundation, "2016 Index of Economic Freedom," Heritage, accessed May 8, 2017, http://www.heritage.org/index/pdf/2016/book/executivehighlights.pdf.

xxxix Freedom House, "Freedom in the World:2016," accessed May 9, 2017, https://freedomhouse.org/report/freedom-world/freedom-world-2016. 
${ }^{x l}$ Weforum, "Ranking:2015," accessed September 20, 2016, http://reports.weforum.org/global-gender-gap-report-2015/rankings/.

xli Globalfirepower, "Military strength," accessed September 25, 2016, http://www.globalfirepower.com/countries-listing.asp

xlii Central Intelligence Agency, "The World Factbook," accessed May 10, 2017, https://www.cia.gov/library/publications/the-world-factbook/geos/xx.html

xliiiThe Heritage Foundation, “2016 Index of Economic Freedom," accessed May 10, 2017, http://www.heritage.org/index/pdf/2016/book/executivehighlights.pdf.

xliv Stephen Kinzer, All the Shah's Men: An American Coup and the Roots of Middle East Terror (New Jersey: Wiley; $2^{\text {nd }}$ edition, 2008) 19.

xlv Ervand Abrahamian, "Chapter 12: A History of Modern Iran," In Introduction to Comparative Politics, ed. Mark Kesselman (Wadsworth Publishing; $5^{\text {th }}$ edition, 2009).

xlvi Ira M Lapidus, A History of Islamic Societies (New York: Cambridge University Press; $2^{\text {nd }}$ edition, 2002) 476-478.

xlvii Fatema Mernissi, Islam and Democracy: Fear of the Modern World (New York: Basic Books; Reissue edition, 2002) 62.

xlviii John L. Esposito, Unholy War: Terror in the Name of Islam (New York: Oxford University Press, 2002) 128.

xlix James A. Bill and Robert Springborg, Politics in the Middle East (New York: Pearson; 5 edition, 1999) 290.

' Fatema Mernissi, Islam and Democracy: Fear of the Modern World (New York: Basic Books; Reissue edition, 2002) 27.

li William L. Cleveland, A History of the Modern Middle East (Westview Press; 5th edition, 2012) 535.

lii James A. Bill and Robert Springborg, Politics in the Middle East (New York: Pearson; 5 edition, 1999) $145-147$. 
liii Stephen Kinzer, All the Shah's Men: An American Coup and the Roots of Middle East Terror (New Jersey: Wiley; $2^{\text {nd }}$ edition, 2008) 1.

liv Karim Sadjadpour, "The Supreme Leader," Iranprimer, August 2015, accessed July 3, 2016, http://iranprimer.usip.org/resource/supreme-leader.

Iv James A. Bill and Robert Springborg, Politics in the Middle East (New York: Pearson; 5 edition, 1999) 170.

lvi Bernard Lewis, The crisis of Islam: Holy war and Unholy Terror (New York: Modern Library; 1 edition, 2003) 26.

Ivii William L. Cleveland, A History of the Modern Middle East (Westview Press; 5th edition, 2012) 536.

Iviii Saeed Kamali Dehghan, "Iranian single women might need father's permission to go abroad," theguardian, January 15, 2013, accessed December 19, 2016, https://www.theguardian.com/world/2013/jan/15/iranian-women-fathers-permissionabroad.

lix Golnaz Esfandiari, "Proposed Bill To Limit Iranian Women's Travel Reportedly Canceled," Radio Free Europe Radio Liberty, February 22, 2013, accessed December 20, 2016, https://www.rferl.org/a/iran-bill-restrict-women-travel/24910177.html.

Ix Center for Human Rights in Iran, "Poll: 70\% of Iranians Dissatisfied With Rouhani on Democracy and Civil Rights," iranhumanrights, January 21, 2017, accessed June 20, 2017, https://www.iranhumanrights.org/2017/01/poll-iranians-dissatisfied-with-rouhani-on-highpriority-issues-of-democracy-and-civil-rights/.

Ixi Azadeh Davachi, "What Iranian Women Want-President Hassan Rouhani's second term is his chance to live up to Iranian women's hopes," usnews, May 24, 2017, accessed June 21, 2017, https://www.usnews.com/news/best-countries/articles/2017-05-24/in-iran-women-wantrights-jobs-and-a-seat-at-the-table.

Ixii Julie Ray, "Iran's Election Brings Desire for Women's Rights Into Focus," Gallup, June 11, 2009, accessed June 21, 2016, http://www.gallup.com/poll/120821/iran-election-bringsdesire-women-rights-focus.aspx . 
Ixii Central Intelligence Agency, "The World Factbook," accessed May 8, 2017, https://www.cia.gov/library/publications/the-world-factbook/geos/xx.html.

Ixiv David F.J. Campbell, “Democracy Ranking 2015,” accessed September 20, 2016, http://democracyranking.org/ranking/2015/data/Scores of the Democracy Ranking 2015 A4.pdf.

Ixv The Heritage Foundation, "2016 Index of Economic Freedom," accessed May 8, 2017, http://www.heritage.org/index/pdf/2016/book/executivehighlights.pdf.

Ixvi Freedom House, "Freedom in the World:2016," accessed May 9, 2017, https://freedomhouse.org/report/freedom-world/freedom-world-2016

Ixvii Weforum, "Ranking:2015," accessed September 20, 2016, http://reports.weforum.org/global-gender-gap-report-2015/rankings/.

Ixviii Globalfirepower, "Military strength," accessed September 25,2016, http://www.globalfirepower.com/countries-listing.asp .

Ixix Central Intelligence Agency, "The World Factbook," accessed June 22, 2017, https://www.cia.gov/library/publications/the-world-factbook/geos/xx.html.

Ixx The Heritage Foundation, "2016 Index of Economic Freedom," accessed June 22, 2017, http://www.heritage.org/index/pdf/2016/book/executivehighlights.pdf

Ixxi Ira M Lapidus, A History of Islamic Societies (New York: Cambridge University Press; $2^{\text {nd }}$ edition, 2002) 33.

Ixxii Bernard Lewis, The crisis of Islam: Holy war and Unholy Terror (New York: Modern Library; 1 edition, 2003) 55.

Ixxiii Bernard Lewis, The crisis of Islam: Holy war and Unholy Terror (New York: Modern Library; 1 edition, 2003) 77.

Ixxiv William L. Cleveland, A History of the Modern Middle East (Westview Press; 5th edition, 2012) 305-309.

Ixxv Ira M Lapidus, A History of Islamic Societies (New York: Cambridge University Press; $2^{\text {nd }}$ edition, 2002) 527-529. 
Ixxvi Fatema Mernissi, Islam and Democracy: Fear of the Modern World (New York: Basic Books; Reissue edition, 2002) 27.

Ixxvii James A. Bill and Robert Springborg, Politics in the Middle East (New York: Pearson; 5 edition, 1999) 171.

Ixxviii Human Rights Watch, “Egypt: Events of 2015," accessed July 1, 2017, https://www.hrw.org/middle-east/n-africa/egypt

Ixxix James A. Bill and Robert Springborg, Politics in the Middle East (New York: Pearson; 5 edition, 1999) 220.

Ixxx Central Intelligence Agency, "The World Factbook," accessed May 8, 2017, https://www.cia.gov/library/publications/the-world-factbook/geos/xx.html.

Ixxxi David F.J. Campbell, “Democracy Ranking 2015,” accessed December 15,2015, http://democracyranking.org/ranking/2015/data/Scores of the Democracy Ranking 2015 A4.pdf.

Ixxxii The Heritage Foundation, "2016 Index of Economic Freedom," accessed May 8, 2017, http://www.heritage.org/index/pdf/2016/book/executivehighlights.pdf.

Ixxxiii Freedom House, "Freedom in the World:2016," accessed May 9, 2017, https://freedomhouse.org/report/freedom-world/freedom-world-2016

Ixxxiv Weforum, "Ranking:2015," accessed September 20,2016, http://reports.weforum.org/global-gender-gap-report-2015/rankings/ .

Ixxxv Globalfirepower, "Military strength," accessed Septer 25, 2016, http://www.globalfirepower.com/countries-listing.asp .

Ixxxvi Central Intelligence Agency, "The World Factbook," accessed May 10, 2017, https://www.cia.gov/library/publications/the-world-factbook/geos/xx.html.

lxxxvii The Heritage Foundation, "2016 Index of Economic Freedom," accessed July 10, 2017, http://www.heritage.org/index/pdf/2016/book/executivehighlights.pdf. 